\title{
How do MNEs invent? An invention-based perspective of MNE profitability
}

\author{
Mario Kafouros ${ }^{1}$, \\ Niron Hashai ${ }^{2}$, \\ Janja Annabel Tardios ${ }^{3}$ and \\ Elizabeth Yi Wang ${ }^{4}$
}

\footnotetext{
${ }^{1}$ Alliance Manchester Business School, University of Manchester, Booth Street West, Manchester M15 6PB, UK; ${ }^{2}$ Arison School of Business, Reichman University, 8 The University St., 4610101 Herzliya, Israel; ${ }^{3}$ Brunel Business School, Brunel University London,

Uxbridge UB8 3PH, UK; ${ }^{4}$ Leeds University Business School, Maurice Keyworth Building, The University of Leeds, Leeds LS2 9JT, UK
}

Correspondence:

M Kafouros, Alliance Manchester Business School, University of Manchester, Booth Street West, Manchester M15 6PB, UK e-mail: marios.kafouros@manchester.ac.uk

\begin{abstract}
Although MNEs create inventions both internally and collaboratively with partners as well as within and across countries, we know very little about the effects that combining such inventive activities have on their profitability. This study develops an invention-based perspective that considers how MNEs' profitability is influenced by the ways they organize the development of inventions across organizational boundaries (internally or collaboratively) and geographic boundaries (within or across countries). This perspective postulates that profitability is not merely driven by advantageous technological endowments but also by how such technological assets have been created. Accordingly, it explains why specific combinations of inventive activities across the two boundaries affect the likelihood of creating breakthrough inventions differently, provide different revenue and cost advantages, and have different effects on MNEs' profitability. It further explains why cross-country inventions contribute more to profitability when they are internalized, while withincountry inventions are more profitable when they are created collaboratively. Journal of International Business Studies (2022) 53, |420-1448.
\end{abstract} https://doi.org/ 10.1057/s41 267-021-00499-y

Keywords: profitability; performance; innovation; technology; collaboration; competitive advantage

The online version of this article is available Open Access

\section{INTRODUCTION}

While the significance of technology in explaining the emergence and competitive advantages of Multinational Enterprises (MNEs) has been central in International Business (IB) theories, a question that has not been addressed is how MNEs can create new technologies in a way that is optimal for enhancing their profitability. Internalization theory (Buckley \& Casson, 1976; Hennart, 1993; Rugman, 1981) and the knowledge-based view see the MNE as the most efficient vehicle for creating and transferring its 'repository' (or stock) of proprietary technologies across borders (Gupta \& Govindarajan, 1994, 2000; Kogut \& Zander, 1993, 1995; Madhok, 1997; Martin \& Salomon, 2003). In addition to benefiting from internalizing the development of technology in their own foreign subsidiaries and R\&D units (Berry, 2014; Castellani, 
Jimenez, \& Zanfei, 2013; Narula, 2014; Zanfei, 2000), MNEs also engage in collaborative technology development, e.g., through international technological alliances (Alcácer, Cantwell, \& Piscitello, 2016; Chen, Zhang, \& Fu, 2019; Narula \& Santangelo, 2009; Robertson \& Gatignon, 1998). Although such internalized and collaborative technology development activities that may occur within and across countries are not perfect substitutes, and therefore coexist within MNEs (Narula, 2001; Narula \& Hagedoorn, 1999), we have a rather limited understanding of the way in which MNEs combine these activities and how different combinations affect their profitability. This limitation is surprising, given that MNEs must deal simultaneously with location and governance decisions (Contractor, Kumar, Kundu, \& Pedersen, 2010; Cuervo-Cazurra, Nieto, \& Rodríguez, 2018; Martínez-Noya \& Narula, 2018).

To understand how MNEs combine internalized and collaborative technology development activities, this study develops an 'invention-based perspective' that offers insights into how MNEs' profitability is influenced by the manner in which they organize the development of each of their inventions ${ }^{1}$ in their portfolio across: (1) organizational boundaries (internally or collaboratively with external partners) and (2) geographic boundaries (within a country or across countries). The usefulness of this perspective lies in explaining how the idiosyncratic way MNEs combine such invention activities in their portfolio affects: (1) the likelihood of creating impactful breakthrough inventions with greater value-adding potential, (2) the associated revenues and costs that are generated by such inventions, and, in turn, (3) the overall profitability of MNEs. Hence, such an inventionbased perspective identifies which combinations of inventing across organizational and geographic boundaries (within-country internal, within-country collaborative, cross-country internal, or crosscountry collaborative) yield better profitability outcomes for MNEs.

In addition to recognizing the coexistence of internalized and collaborative international invention activities, the proposed model highlights the theoretical value of showing that variations in the combinations of inventive activities across organizational and geographic boundaries lead to different revenue and cost advantages, and, in turn, make MNEs perform differently. The underlying reasoning of the study suggests that, due to the nature of invention activities, the marginal revenues from distributing invention across both the geographic and organizational boundaries increase in a diminishing manner, while the marginal costs of doing so increase exponentially. Accordingly, it shows that (and explains why) combinations of 'cross-country and internal' and 'within-country and collaborative' invention activities that constitute 'balanced' approaches to invention enhance MNE profitability more than highly concentrated ('within-country and internal') or highly distributed approaches to invention ('crosscountry and collaborative'). By simultaneously considering the geographic and organizational boundaries of invention, the proposed model identifies which specific combinations of invention activities are more effective for generating breakthrough inventions and enhancing MNEs' profitability, and thereby explains profitability outcomes that cannot be well explained when adopting firm-level analyses.

The invention-based perspective developed in this study enriches the knowledge-based view (Gupta \& Govindarajan, 1994, 2000; Kogut \& Zander, 1993, 1995; Madhok, 1997; Martin \& Salomon, 2003) by clarifying 'how' an MNE's repository of technological inventions should be developed. It therefore complements explanations that suggest that an MNE's success is a function of its repository of 'advantageous' technological assets but do not specify how such 'advantageous' technologies can be created. A key theoretical implication of this perspective is that MNE profitability is not merely driven by richer technological endowments but also by specific combinations of inventive activities that increase the propensity of inventions to become impactful and, thereby, generate more value and profits for MNEs. This explanation of the drivers of MNE profitability differs from and extends firm-level explanations concerning global R\&D locations and/or technological alliances that do not specify how exactly MNEs can invent in an optimal, profit-maximizing, way. This distinction is particularly important because, as our analysis shows, while an MNE may have R\&D units and invent in several countries, it might be that the majority (or even all) of its inventions are developed locally within each of these countries, with very few of its inventions being developed across different countries. In this instance, an MNE may conduct R\&D abroad without truly engaging in cross-country invention. Similarly, an MNE may engage in multiple technological alliances, but still develop most of its 
inventions internally. Therefore, ignoring such differences may lead to inaccurate conclusions about how MNEs develop their technological inventions and which combinations of inventive activities drive MNE profitability.

The next sections introduce our model and develop a number of hypotheses, which are subsequently tested by analyzing 46,580 inventions (patents) developed during the 2003-2012 period by 100 UK-headquartered MNEs, their 4,800 subsidiaries, and their approximately 1,100 partners located in 112 countries.

\section{THEORETICAL BACKGROUND}

\section{Inventing Across Geographic Boundaries}

The extant IB literature has shown that MNEs leverage their international scope to establish or acquire R\&D subsidiaries and develop new inventions in different countries (Almeida, 1996; Berry, 2014; Ghoshal, 1987; Lahiri, 2010; Von Zedtwitz \& Gassmann, 2002). As technological knowledge is geographically localized (Jaffe, Trajtenberg, \& Henderson, 1993), MNEs must expand abroad to acquire new technologies and knowledge (Dunning, 1996; Narula, 2014). As the competitive advantages of MNEs rely on acquiring diverse technological knowledge from multiple countries (Asmussen, Pedersen, \& Dhanaraj, 2009; Cantwell, 1995), MNEs form international networks of $R \& D$ subsidiaries that evaluate, absorb, and integrate globally dispersed knowledge (Doz, Santos, \& Williamson, 2001; Kafouros, Wang, Mavroudi, Hong, $\&$ Katsikeas, 2018).

Yet, the concept of cross-country invention, which is the focus of our analysis, differs from R\&D internationalization in two important ways. First, MNEs may conduct R\&D in multiple countries but still choose to develop each focal invention within each of these countries, rather than across two or more countries. Within-country invention effectively means that the developers of a focal invention are all located in the same country. By contrast, in cross-country invention, inventors from different countries contribute to the development of the invention. A second important difference is that, while MNEs typically disperse R\&D units across several countries, the cross-country development of a focal invention involves in most cases inventors from only two countries. Therefore, although cross-country invention is not a purely dichotomous concept, its scale at the invention-level is rather limited, as it rarely involves inventors from more than two or three countries. Evidence from our sample of inventions (patents) shows that the geographic distribution of developing a specific patent predominantly pertains to up to three countries (accounting for 99.8\% of total technologies). Data for the UK-based pharmaceutical MNE AstraZeneca demonstrate this point. As shown in Figure 1, while AstraZeneca had eight R\&D sites (seven of them foreign), our data show that over $97 \%$ of its patents were developed in up to two countries.

With respect to geographic boundaries, the IB literature has focused on two dominant theoretical perspectives, offering complementary predictions concerning the development of inventions. One perspective suggests that cross-country technology transfer decreases the efficiency of interactions and knowledge flows between individuals (Buckley \& Carter, 2004; Jaffe et al., 1993; Narula, 2014). Such interactions are resource-intensive and costly, as cross-country differences require inventors to communicate in different languages and to accommodate different cultural, legal, and regulatory systems (Kogut \& Zander, 1993; Zaheer, 1995). These variations also increase the difficulty of protecting inventions, create frictions, and decrease the quality of communication, while increasing coordination costs in cross-country inventions (Contractor et al., 2010; Cummings \& Kiesler, 2007; Gulati \& Singh, 1998).

Another dominant theoretical perspective in the IB literature suggests that knowledge residing in different countries improves technological diversity (Berry, 2014), as it provides additional professional networks and social interactions (Almeida \& Kogut, 1999; Feinberg \& Gupta, 2004). Combining knowledge from different national innovation systems (Furman, Porter, \& Stern, 2002) can be particularly beneficial, leading to novel and valuable technology combinations that cannot be easily achieved when inventing within a single country (Berry, 2014; Kogut \& Zander, 1993; Martin \& Salomon, 2003). Accordingly, inventions that are developed across countries are expected to be used and get cited more than those that are developed domestically (Chen et al., 2019). Hence, experimentation with cross-country invention (Alnuaimi, Singh, \& George, 2012; Phene \& Almeida, 2008) increases the ability of MNEs to generate breakthrough inventions (Phene, Fladmoe-Lindquist, \& Marsh, 2006), which are typically of greater value 


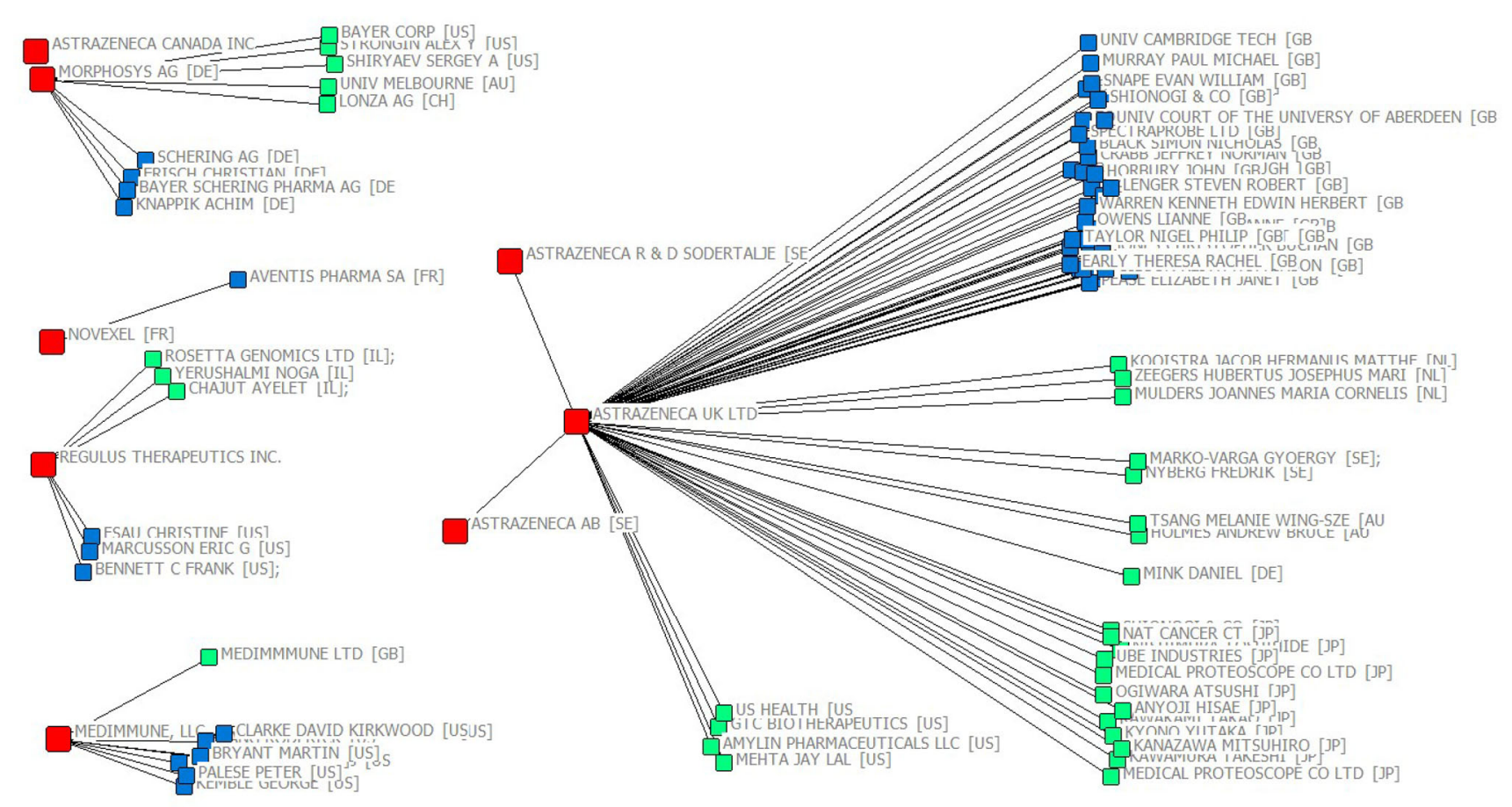

Figure 1 The invention network of AstraZeneca. This figure, developed using Ucinet and NetDraw (Borgatti, Everett, \& Freeman, 2002), is based on the company's patents in the 2003-2012 period. The squares in red represent MNE headquarters and subsidiaries, the blue squares the collaborators from the same country, and the green squares the collaborators from a different country. The squares are accompanied by the name of the respective headquarters, subsidiary or collaborators and abbreviated country of operation in brackets. The lines illustrate the existence of patent collaborations.

(Lerner, 1994; Trajtenberg, 1990) and thereby enhance MNEs' revenues.

Combining the above IB perspectives therefore suggests that, although within-country invention is less costly, it cannot facilitate diversity (Belderbos, Leten, \& Suzuki, 2013; Cuervo-Cazurra et al., 2018). In contrast, inventing across countries is complex and difficult to coordinate (Mudambi \& Swift, 2011; Sanna-Randaccio \& Veugelers, 2007), but allows inventors to access diverse knowledge (Castellani et al., 2013; Kafouros, Buckley, \& Clegg, 2012) and to create impactful breakthrough inventions that generate additional revenues.

\section{Invention Across Organizational Boundaries}

In a similar vein, the collaborative development of inventions differs from an MNE's portfolio of international technological alliances. Although an MNE can have several foreign partners, the development of a focal invention is most often conducted in-house or involves inventors from only one partner. Evidence from our sample of inventions shows that the organizational distribution of developing a specific patent predominantly pertains to one or two external partners (which, together with internal development, account for $99.5 \%$ of the total). Reverting to Figure 1, while AstraZeneca had $70 \mathrm{R} \& \mathrm{D}$ partners (two thirds of whom are foreign), about $96 \%$ of its patents were developed internally or with only one partner.

IB research on the role of organizational boundaries has been dominated by two key theoretical perspectives. Extant IB theories highlight the central role that technology plays in driving competitive advantage and superior profitability in MNEs (Buckley \& Casson, 1976, 1998; Kogut \& Zander, 1993, 1995; Rugman, 1981). These theories essentially suggest that interorganizational boundaries decrease the efficiency of interactions between inventors belonging to different firms. They accordingly predict that the collaborative development of inventions increases the probability of proprietary knowledge leakage (Alcacer \& Oxley, 2014; Cassiman \& Veugelers, 2002; Frishammar, Ericsson, \& Patel, 2015) and requires costly coordination (Zanfei, 2000). By contrast, internal invention helps in coordinating inventive activity and protects inventions, but makes the assimilation and recombination of external technological knowledge less efficient, especially when it comes to the creation 
and transfer of complex technologies and tacit knowledge (Adler \& Hashai, 2007; Cuervo-Cazurra et al., 2018; Gupta \& Govindarajan, 2000; Kogut \& Zander, 1992; Martin \& Salomon, 2003).

Other IB studies emphasize that international collaborative development of inventions is advantageous for gaining diverse and complementary knowledge and for leveraging existing knowledge more effectively, leading to more valuable inventions (Hsuan \& Mahnke, 2011; Narula \& Santangelo, 2009; Robertson \& Gatignon, 1998). The work of Hagedoorn and Schakenraad (1994), Lew, Sinkovics, Yamin and Khan (2016), and Monteiro, Mol and Birkinshaw (2017), among others, highlights that international technological collaboration leads to more impactful inventions, reduces time-tomarket, and assists in competing in new technological areas (Chen et al., 2019; Martínez-Noya \& Narula, 2018). As a result, international collaborative invention helps to generate additional revenues.

Taken together, the above IB perspectives suggest that, although internal invention helps coordination, makes technology transfer more efficient, and decreases technology leakage, it is confined to less diverse technology domains residing within the MNE. Collaborative invention is more complex and costly, but it assists in accessing diverse knowledge that increases the likelihood of developing distinct and impactful inventions (Chen et al., 2019; Lew et al., 2016; Patel, Fernhaber, McDougall-Covin, \& Have van der, 2014). As impactful inventions are more valuable (Lerner, 1994; Trajtenberg, 1990), collaborative invention can generate additional revenues.

\section{CONCEPTUAL FRAMEWORK: AN INVENTION- BASED PERSPECTIVE}

\section{Concentrated and Distributed Invention Activities}

The above theoretical background draws two parallels between the geographic and organizational boundaries of invention. Both cross-country and collaborative invention can be seen as 'distributed' approaches to the development of inventions. They may lead to impactful inventions and increase revenues, but they are also costly and less effective in controlling, sharing, and integrating knowledge across countries and partners. By contrast, both within-country and internal invention represent 'concentrated' approaches to the development of inventions. They make a limited contribution to the development of impactful inventions and revenues, but they are less costly and more effective in terms of transferring, organizing, and monitoring technological knowledge.

As summarized in Figure 2, viewing MNEs' invention activity across geographic and organizational boundaries as a combination of concentrated and distributed activities can help us derive four types of invention activities: within-country internal (lower left); within-country collaborative (upper left); cross-country collaborative (upper right); and cross-country internal (lower right). For the development of a given invention, MNEs must

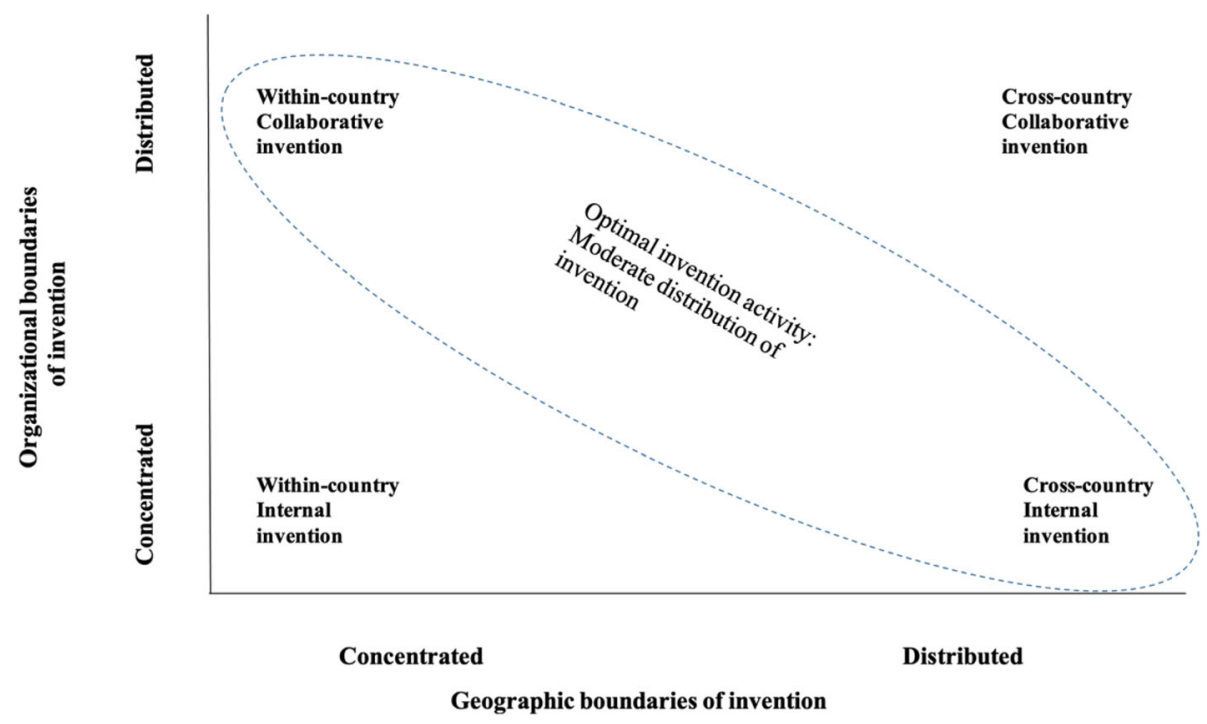

Figure 2 Distributed and concentrated invention activities. 
choose only one of these activities (i.e., these activities are mutually exclusive at the invention level). However, to develop their portfolio of inventions, MNEs typically use several invention activities. However, they differ considerably in the extent to which they adopt each of these activities within their portfolios. Hence, at the MNE portfolio level, the two axes composing Figure 2 should be thought of as a spectrum of activities portraying the extent to which MNEs distribute the development of inventions along geographic and organizational boundaries, respectively. This, in turn, determines whether an MNE's invention activity is concentrated or distributed. A key premise in our conceptual framework is that the way in which MNEs develop their inventions is an important source of heterogeneity in MNE profitability. Accordingly, it predicts how the four invention activities that MNEs adopt to develop their invention portfolio influence the ability of MNEs to generate impactful breakthrough inventions ${ }^{2}$ and increase their profitability.

The IB theories discussed in the previous section suggest that, when an MNE's invention portfolio is dominated by concentrated invention activities, it tends to be less costly, but its contribution to the development of breakthrough inventions and their resulting revenues is also low. They also suggest that the generation of breakthrough inventions and revenues is likely to be higher when an MNE's invention portfolio is dominated by distributed inventions, but in such cases the associated costs are also high. However, it remains unclear whether and how MNEs can benefit from breakthrough inventions and the increased revenues resulting from distributed inventions, while also confining the costs of such inventions.

We develop an invention-based perspective that contends that MNEs can manage these trade-offs by distributing the development of each invention along one of the two boundaries (geographic and organizational), while concentrating it along the other (rather than concentrating or distributing development across both boundaries). This means that, when invention is distributed across countries, the organizational boundary of invention should be internalized and when, it is concentrated within a country, it should be developed in collaboration with partners.

Building on this premise, the invention-based perspective explains why, at the portfolio level, some invention activities are more advantageous than others for increasing MNE revenues, reducing costs, and hence enhancing profitability (see Figure 3). Specifically, it makes two key predictions: (1) MNE revenues resulting from breakthrough inventions increase at a higher rate when an MNE distributes the development of inventions across either geographic or organizational boundaries, but decrease when it concurrently distributes the development of inventions across both boundaries; (2) the associated costs of developing inventions increase at a lower rate when inventions are partly concentrated, but increase exponentially when an MNE distributes the development of its inventions across both boundaries. This, in turn, means that 'cross-country internal' invention and 'withincountry collaborative' invention allow a moderate extent of distribution (see Figure 2). This results in a more effective development of breakthrough

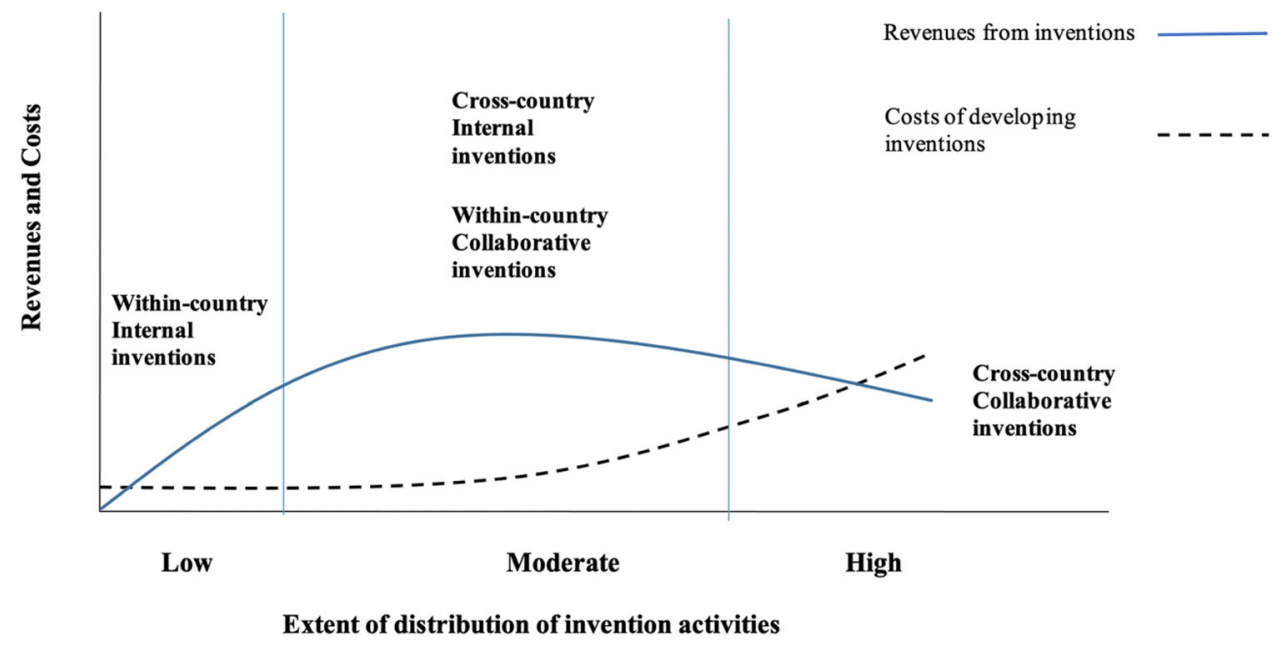

Figure 3 Revenues and costs in concentrated and distributed MNE invention portfolios. 
inventions and in the highest positive difference between revenues and costs (i.e., profitability).

The following sub-sections substantiate the above contentions and explain how differences in the revenue generation and the costs of distributed and concentrated development of inventions along geographic and organizational boundaries affect the generation of breakthrough inventions and MNE profitability.

\section{Developing Inventions Using Concentrated and Distributed Activities}

\section{Consequences for breakthrough inventions}

It has long been established that technological diversity, which can be achieved along the geographic and/or the organizational boundary, has a profound effect on firms' ability to develop impactful, breakthrough inventions (Phene et al., 2006; Srivastava \& Gnyawali, 2011). Hence, MNEs that predominantly rely on within-country and internal invention are less likely to generate breakthrough inventions compared to MNEs that develop inventions across countries or in collaboration with other firms. However, there are also limits to the benefits of technological diversity. When MNEs predominantly rely on cross-country and collaborative invention, the level of diversity becomes particularly high and may reach its limits. In such instances, MNEs need to coordinate inventors both across countries and across different firms. This, in turn, increases the complexity and overall difficulty of identifying and supporting the most promising projects, as well as effectively managing inventor teams. As a result, the ability of MNEs to combine geographic and organizational diversity is compromised. We therefore expect the rate of breakthrough inventions to decrease when MNEs invent both across countries and with external partners.

Two main factors constrain the ability of MNEs to handle the information processing demands and the complexities of concurrently developing inventions across countries and in collaboration. First, the cognitive capacity of individual managers (responsible for technological activities) to learn and absorb knowledge is limited (Zahra \& George, 2002). As managers are boundedly rational, the MNE cannot effectively absorb and process unlimited amount of knowledge, and so becomes less effective in managing highly complex invention portfolios that exhibit very high levels of diversity. Second, managerial resources are limited in the short run (Mahoney \& Pandian, 1992; Penrose, 1959; Teece, 1982), and new managers cannot be hired at an infinite rate from the market (Penrose, 1959). Once again, the amount of knowledge an MNE can absorb and process is constrained, which, in turn, inhibits the simultaneous management of cross-country and collaborative invention projects. Such knowledge-processing limitations and associated complexities restrict the number of technological diversity opportunities an MNE can exploit, leading to a trade-off between cross-country and collaborative development of inventions (Anand \& Delios, 2002; March, 1991).

Let us consider the above reasoning from the point of view of an MNE engaging in cross-country invention. The geographic-related benefits of crosscountry invention facilitate the creation, transfer, and combination of diverse and complementary knowledge (Berry, 2014) that is likely to lead to novel and impactful inventions (Almeida \& Kogut, 1999; Monteiro \& Birkinshaw, 2017; Phene et al., 2006). However, combining cross-country and collaborative invention increases the complexity considerably, and requires significant managerial capacity to monitor joint projects and to understand partners' technological advantages (Stuermer, Spaeth, \& Krogh Von, 2009). It also puts under pressure the capacity of MNEs' managerial systems to process the knowledge of external organizations (Laursen \& Salter, 2006; Stuermer et al., 2009). The fact that inventive activities have to be completed (often jointly) across organizational boundaries further increases the number of decisions that have to be taken (Gulati \& Singh, 1998), and requires the creation of efficient interorganizational interfaces with partners (White \& SiuYun Lui, 2005; Zanfei, 2000). These complexities reduce the efficiency of developing inventions and the likelihood of generating breakthrough inventions. By contrast, such complexities are lower when cross-country invention is conducted within the MNE's organizational boundaries.

Let us also consider the above reasoning when MNEs engage in collaborative invention. Combining the MNE's own technological expertise with that of external partners helps the development of new skills, resources, and capabilities (Ahuja, 2000; Cassiman \& Veugelers, 2006; Chesbrough, 2006), and therefore helps the development of impactful inventions (Chen et al., 2019; Frost \& Zhou, 2005; Nieto \& Santamaría, 2007; Noorderhaven \& Harzing, 2009). Collaboration enhances the impact of inventions by helping MNEs become attuned to 
environmental changes (Chesbrough, 2006; Robertson \& Gatignon, 1998) and by improving their response to market demand and technological disruption (Rigby \& Zook, 2002). Nevertheless, information-processing demands in cross-country invention stretch managers and administrative systems (Hitt, Hoskisson, \& Kim, 1997; Lahiri, 2010; Narula, 2014). In turn, combining crosscountry and collaborative invention increases the complexity of developing inventions to the extent where the ability of the MNE to develop breakthrough inventions is compromised. By contrast, such limitations and complexities can be kept at a lower level when collaborative invention is conducted within a single country.

Figure 4 portrays how the above views concerning the advantages and pitfalls of technological diversity for generating breakthrough inventions relate to different invention activities at the MNE's invention portfolio level. This figure shows that 'within-country internal' inventions result in weaker advantages and weaker pitfalls of technological diversity. 'Cross-country collaborative' technology inventions result in stronger advantages, but also stronger pitfalls of technological diversity. It is 'cross-country internal' and 'within-country collaborative' inventions that exhibit stronger advantages and weaker pitfalls for generating breakthrough inventions. We therefore hypothesize that:

Hypothesis 1: Cross-country internal and within-country collaborative invention activities increase the development of breakthroughs in MNEs more than within-country internal and cross-country collaborative invention activities.

\section{Consequences for profitability}

Increasing the development of breakthrough inventions through cross-country internal or within-country collaborative invention helps MNEs improve the overall value of their invention portfolios (Lerner, 1994; Trajtenberg, 1990), build stronger competitive advantages, and make their commercialization more effective (Belderbos, Carree, \& Lokshin, 2004). In turn, these invention activities allow MNEs to use their technological discoveries as a means to create new products and enter new markets, thereby increasing revenues more than when they adopt other invention activities.

Within-country internal invention offers limited access to external technological knowledge and typically converges around the MNE's existing technological knowledge base and capabilities (Frost \& Zhou, 2005; Mowery, Oxley, \& Silverman, 1996). It therefore limits the opportunities for creating, transferring, and combining diverse technological knowledge, which can serve as a source for generating additional revenues. Cross-country internal invention allows MNEs to increase their revenues by leveraging cross-country technological knowledge (but not overstretching it by also engaging in collaborative invention), while within-

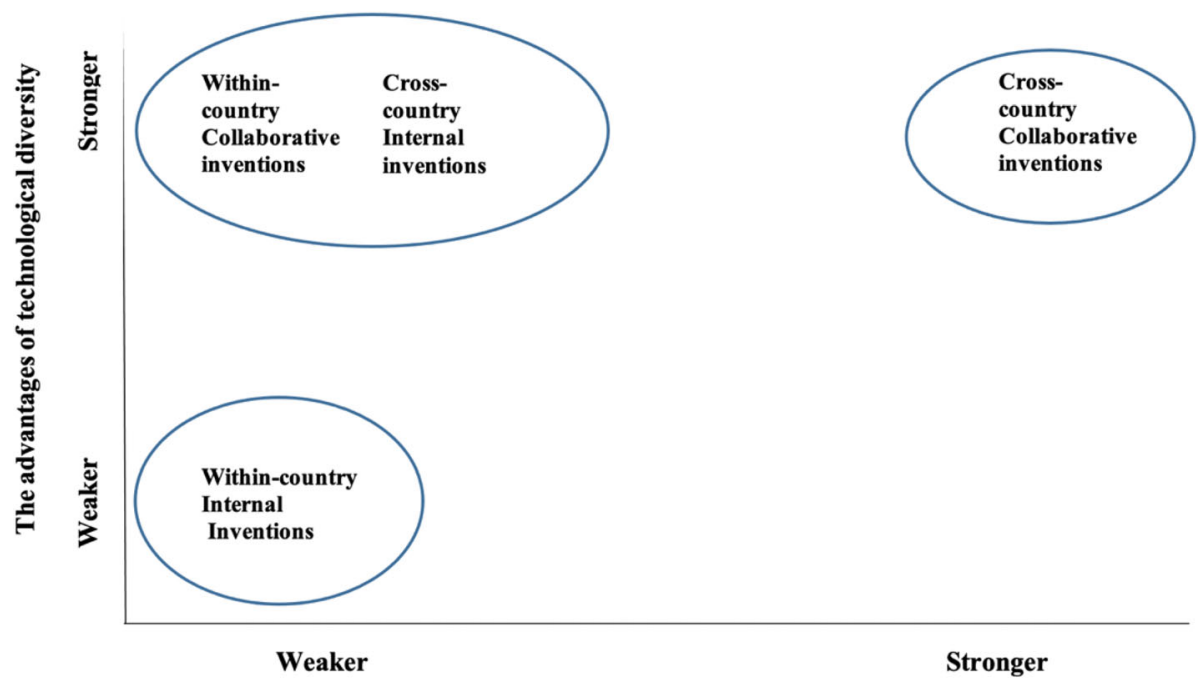

The pitfalls of technological diversity

Figure 4 The advantages and pitfalls of technological diversity for breakthrough inventions. 
country collaborative invention does so by leveraging collaboration with external partners (but not overstretching it by also engaging in cross-country invention). This point is portrayed by the concave shape of the revenue curve in Figure 3. Yet, when considering the consequences of invention for profitability, one must also consider its cost implications.

In essence, cross-country invention requires inventors and managers to bear the costs of geographic, cultural, and institutional differences (Almeida \& Phene, 2004; Berry, 2014; Delios \& Henisz, 2003). These costs escalate when international collaborators from external organizations are involved, increasing the need to overcome both cross-cultural and transactional barriers across firm boundaries and resulting in 'double layered acculturation' (Barkema, Bell, \& Pennings, 1996; Capaldo \& Petruzzelli, 2011). This combination also increases the number of interdependencies a focal MNE faces across its entire portfolio of inventions, leading to exponentially higher transaction, communication, and coordination costs (Goerzen \& Beamish, 2005; Lahiri, 2010; Leiponen \& Helfat, 2010). For instance, it is particularly difficult for MNE managers who coordinate inventors across both countries and different firms to avoid duplication in inventive efforts and resolve conflicts.

Cross-country invention requires decomposing tasks across borders. It also requires extensive coordination of inventors from different institutional and cultural settings (Almeida \& Phene, 2004; Berry, 2014), thus consuming considerable managerial time and resources. While collaborative invention is likely to exacerbate the costs of crosscountry invention, internal invention can keep such costs at a moderate level. Hence, cross-country internal invention is expected to increase costs less than cross-country collaborative invention.

Likewise, combining technological knowledge that is developed with external partners within a country is expected to increase costs less than coordinating collaborative development of inventions across countries. Confining knowledge exchange, coordination, and monitoring within a country keeps the costs, inefficiencies, and complexities of invention at a moderate level (Jaffe et al., 1993). Therefore, as Figure 3 shows, the costs of cross-country collaborative invention within the MNE's invention portfolio increase exponentially relative to the costs of cross-country internal invention or the costs of within-country collaborative invention.

Two main reasons explain this effect. First, transaction costs are particularly high in crosscountry collaborative invention (Narula \& Verbeke, 2015). Compared to internal invention, collaborative invention induces greater appropriability risks (Teece, 1986; West, Salter, Vanhaverbeke, \& Chesbrough, 2014), as well as imitation and knowledge leakage threats (Gulati \& Singh, 1998) across the MNE invention portfolio. As collaborative inventions are co-owned by multiple partners, they incur higher monitoring costs (Gans \& Stern, 2003; Khanna, Gulati, \& Nohria, 1998), increase frictions, and result in unpredictable outcomes. Second, cross-country collaborative invention involves costs associated with the assimilation of knowledge obtained from partners (Kogut \& Zander, 1993, 1995) and the bridging of different knowledge bases (Barkema et al., 1996; Miller, Fern, \& Cardinal, 2007). Thus, the assimilation and integration of knowledge from external collaborators and from different countries add significantly to the demands placed on resources and the time of managers in MNEs. The above discussion indicates that within-country collaborative and cross-country internal invention are more advantageous than cross-country collaborative invention, both in terms of revenues and costs.

In parallel, the combination of within-country and internal invention is cost-effective both geographically and organizationally, but, as noted above, it confines MNEs to the technological knowledge residing within a country and within a single organization, thus limiting the revenue streams MNEs can gain from their invention efforts. As shown in Figure 3, the difference between these revenues and costs is likely to be small, thus leading to weaker (or even negative) effects on the profitability of MNEs.

Overall, cross-country internal and within-country collaborative invention activities help MNEs keep the associated costs at a moderate level while maintaining a stronger stream of revenues. Crosscountry collaborative invention activities increase exponentially the associated costs and are also less effective than cross-country internal and withincountry collaborative inventions for generating revenues. Within country-internal inventions result in both low revenues and costs. Hence: 
Hypothesis 2: Cross-country internal and within-country collaborative invention activities increase MNE profitability more than withincountry internal and cross-country collaborative invention activities.

In summary, we hypothesize that combinations of distributed and concentrated invention activities across geographic and organizational boundaries (i. e., combining cross-country and internal, or within-country and collaborative invention) enhance the development of breakthrough inventions within the MNE more than purely concentrated invention activities (i.e., combining withincountry and internal) or purely distributed invention activities (i.e., combining cross-country and collaborative). This prediction rests on the premise that distributing the development of invention development along one boundary is most effective for creating distinct technological knowledge that, in turn, increases the likelihood of developing impactful inventions. Similarly, the combination of distributed and concentrated invention activities helps MNEs increase their revenues by distributing the development of inventions along one boundary, while maintaining costs relatively low by concentrating the development of inventions along the other. As indicated in Figure 2, these combinations therefore constitute the optimal invention activities for profitability. The next sections empirically test these predictions and present additional analyses.

\section{SAMPLE}

To test our hypotheses, we collected data on the invention activities of a sample of large UK-headquartered MNEs over the 2003-2012 period. We used Bureau Van Dijk Fame (Arora, Belenzon, \& Rios, 2014) to collect financial and organizational data. The MNEs in this sample vary significantly in the four invention activities. To ensure that there is sufficient variation, we sampled MNEs operating in a variety of industries, rather than focusing on one high-technology industry. We excluded MNEs in non-manufacturing sectors.

To capture the development of inventions in MNEs, we collected data on the patent portfolio of each MNE (e.g., Salomon \& Jin, 2008; Wagner, Hoisl, \& Thoma, 2014). We collected patent data from the European Patent Office (EPO) Espacenet database, which has been used widely (e.g., Belderbos et al., 2013) and offers detailed information on millions of patents developed worldwide. Although patent data do not capture all inventive activities (Griliches, 1998), they reflect the delegation of activities used to develop different inventions (see, e.g., Arora et al., 2014).

Following prior studies (e.g., Arora et al., 2014), we use firm name and address as identifier in the EPO database, while controlling for any name or address change in the relevant time period (given by the Fame database). To capture the invention activities of MNEs in a comprehensive way, we followed Kafouros and Aliyev (2016) and collected data on patents for each of the MNE headquarters and their majority-owned subsidiaries (those with more than 50\% of ownership) over the 2003-2012 period. We collected patent application data because compared to granted patent data, they are a more comprehensive indicator of firms' invention scope (Belderbos et al., 2013). The final sample includes 46,580 patents developed by 100 MNEs with 4,800 subsidiaries and approximately 1,100 partners located in 112 countries.

\section{MEASURES}

\section{Dependent Variables}

To measure breakthrough inventions, we use the indicator provided in the OECD database that defines breakthrough inventions as the top $1 \%$ of cited patents, based on a 5-year forward citation count (see Squicciarini et al., 2013 for further details), as a measure of the value of technological inventions (Fleming \& Sorenson, 2001, 2004; Kaplan \& Vakili, 2015). Previous research has found that citations are heavily skewed (Singh \& Fleming, 2010; Trajtenberg, 1990) and used cut-off points ranging from top $1 \%$ to top 5\% of citation counts (e.g., Kaplan \& Vakili, 2015; Phene et al., 2006; Singh \& Fleming, 2010). We follow a more conservative assumption and define breakthrough inventions as the patents in the top 1\% of citation ranks within their technology classes (Phene et al., 2006). Calculating the percentile points within technology classes (IPC 4-digit level) ensures that the measure is specific to the technology class and is not affected by technology-specific differences in patent citation patterns. Our dependent variable is a weighted average measure of a focal MNE's patents that meet the above criteria to become a breakthrough invention. We estimated the MNElevel variable, Breakthrough Inventions, using the number of breakthrough inventions for each 
patenting subsidiary and year, and weighting the subsidiary-level counts by the subsidiary's total number of patents in a respective year.

We use the widely adopted measure for profitability, return on assets (ROA), at the MNE level. Prior research has long established that firms that repeatedly introduce new technologies (inventions) achieve sustained profitability (Roberts, 1999). ROA reflects efficiency in the utilization of the firm's assets (Chan, Hwang, \& Burgers, 1989), and is particularly applicable to MNEs (Hitt et al., 1997; Lee \& Song, 2012; Qian, Khoury, Peng, \& Qian, 2010). ROA is superior to other accounting indicators of profitability such as return on sales (ROS) or return on equity (ROE). ROE is highly sensitive to differences in capital structures, while ROS may not properly reflect causality as many of our control variables are a function of firm sales (Hitt et al., 1997). Because many firms use patents to produce products shortly after the patent application (and in some cases before patent granting), patenting may affect profitability relatively quickly. Nevertheless, to explore the sensitivity of the results and capture possible lags between MNE patenting and profitability, we use both concurrent ROA measures and lagged measures of up to three years. For this purpose, we expanded the data collection for ROA to include years from 2002 to 2015 .

\section{Independent Variables}

We capture MNEs' invention activities by examining their patenting patterns along the geographic and organizational boundaries over the 2003-2012 period. We identified all the majority-owned subsidiaries of each MNE (domestic and foreign) and collected information on where they are located. We then identified the patents granted to the subsidiaries and headquarters and examined the information given in the patent document. The first step was to determine the geographic boundary of patent development using, as in established practice (Berry, 2014), inventor location data. This involved examining all the patents within an MNE's invention portfolio. Patents where all inventors reside in the same country are classified as within-country invention, while patents where inventors reside in more than one country are classified as cross-country invention.

The second step was to determine the organizational boundary of patent development. Although we would have ideally used employee names and matched them to the inventor information, we did not have access to such data. Prior studies relied on other pieces of information in the patent document. For example, studies sampling from the US patent database found patent assignee information, indicating patent ownership, to be a reliable proxy for the organizational boundary in which patents were developed (Arora et al., 2014; Yamin \& Otto, 2004). Patent ownership within the EPO database is recorded via the "patent applicant" information, which has been used in prior studies to determine the organizational origin of a patent (e.g., Corsino, Mariani, \& Torrisi, 2019; Dachs \& Pyka, 2010; Wagner et al., 2014). Therefore, we used the 'patent applicant' information (name and address) to determine the organizational boundary of patents. Whenever a patent listed an organization that does not belong to the MNE's portfolio of subsidiaries as co-applicant, it was coded as a collaborative invention. The same applied to individuals listed on the patent document as co-applicants. Whenever applicants belonged to the MNE subsidiary portfolio, they were coded as an internal invention (in addition to cases where only one subsidiary, or the headquarters, was listed as applicant).

Our key independent variables represent a combination of the boundaries discussed earlier. Specifically, 'within-country internal invention' are patents where all inventors are located in one country, and all applicants belong to the MNE units (headquarters and/or its subsidiary portfolio). 'Within-country collaborative invention' are patents where all inventors are located in one country, but at least one co-applicant does not belong to the MNE's units. 'Cross-country internal invention' are patents where at least one inventor is located in a different country, but all applicants belong to the MNE's units. 'Cross-country collaborative invention' are patents where at least one inventor is located in a different country, and at least one co-applicant does do not belong to the MNE's units.

All four measures are expressed as ratios over total patents (i.e., the count of patents in one of the above classifications over of the count of total patents). All patents generated by each subsidiary and the headquarters of the MNE in each year have been included in our measure. Measuring the variables as ratios normalizes for the patent counts and accounts for differences in the scale of patenting among MNE subsidiaries. Although we collected data for each of the units of the MNE separately, the hypotheses focus on the entire portfolio of inventions held by the MNE. Accordingly, the final measure that we use for the entire 
MNE is the weighted mean of the patents (as per each subsidiary's contribution) of all the MNE units that engaged in patenting (and for each year).

\section{Control Variables}

We control for an extensive number of firm-, industry- and country-level factors that may influence MNE breakthrough inventions and profitability.

\section{Firm-level controls}

As a control of the MNE's invention output in each year, our model includes a measure for patent output (annually), expressed as the number of patents assigned to the MNE per year (Decarolis \& Deeds, 1999). Additionally, many MNEs choose to patent within a country. To account for potential within-country bias in patenting, we use a control variable that captures the ratio of within-country patents to total patents for each MNE. Our model also controls for the number of patent-generating subsidiaries, which is operationalized as a count measure of subsidiaries that developed patents. Controlling for the latter is important because it captures an MNE's competence-creating mandate to subsidiaries that may affect the impact of their inventions and their profitability (Cantwell \& Mudambi, 2005). Also, we include a measure of intangible assets to capture other knowledge-based assets that may affect MNE performance and innovation such as trademarks, copyrights, registered designs, and proprietary land use rights (Hall, 1993).

As breakthrough inventions and profitability (ROA) in previous years may influence future breakthrough inventions and profitability (ROA), we add a one-year lagged measure of breakthrough inventions and profitability (ROA). To account for economies of scope (Tallman \& Li, 1996), we use a product diversity measure that is operationalized as the total number of industries in which MNEs operate their major businesses (based on four-digit SIC codes). In addition, we introduce a count measure of the number of countries in which the MNE operates using the MNE's subsidiary location information, as a control for MNEs' foreign country dispersion (Delios \& Beamish, 1999). Moreover, we control for tangible assets and number of employees, as these factors have been shown to affect an MNE's inventions and profitability (Decarolis, 2003; Lu \& Beamish, 2001). We also control for MNE age (in years) and size (total sales) to account for potential economies of scale and for access to financial resources which larger and established firms may enjoy (Veugelers, 1997).

\section{Industry-level controls}

Following established practice in the performance and innovation literatures (Hawawini, Subramanian, \& Verdin, 2003; Sørensen \& Stuart, 2000), our controls also include industry effects. For industry dummies, we group MNEs into ten major manufacturing sector categories (Golovko \& Valentini, 2011) that are distributed as follows: food, beverages, and tobacco products (7\%); textiles and leather products $(1 \%)$; wood, furniture, paper and paper products $(4 \%)$; coal, petroleum, and chemicals (16\%); pharmaceutical products, $(5 \%)$; rubber and plastic products (6\%); basic metals and metal products (8\%); computer, electrical equipment, and optical products $(15 \%)$; machinery, vehicles, and equipment (21\%); and other manufacturing (17\%).

We also control for the mean profitability of each industry using the respective average values of profit margins for the whole population of UK firms in the same industry. As in other studies, we account for industry conditions by controlling for industry demand, defined as the annual percentage change in sales in each industry, and for industry concentration, using a Herfindahl index of the market share of the largest four firms (Derfus, Maggitti, Grimm, \& Smith, 2008). The main results control for industry demand and concentration in the UK, but, in the robustness tests section, we also control for such effects globally. Apart from industry dummies, we further include a variable to distinguish between industries of high, mediumhigh, medium-low, and low technological opportunities (ranging from 1 for high tech to 4 for low tech; Grimpe \& Sofka, 2009). Given the large number of industry and time dummies, we do not report these results in the tables.

\section{Country-level controls}

Following established practice (Ivus, Park, \& Saggi, 2017; Kafouros et al., 2018), we develop a measure of intellectual property rights (IPR) effectiveness using the annual mean of lagged IPR indices of the countries in which the MNE operates. These indices rely on data from Park's (2008) expanded dataset that captures five different aspects: patentability coverage, treaties membership, duration of protection, legal enforcement, and other patent right restrictions. ${ }^{3}$ To account for MNEs' access to globally distributed knowledge within and across 
industries, we replicate the approach used by previous studies in the knowledge spillovers literature (e.g., Kafouros et al., 2012) and incorporate a global knowledge reservoirs variable. This approach relies on capturing data on the $R \& D$ investments undertaken by all firms in each given country over the period of our sample. R\&D investments, in turn, lead to the creation of pools or reservoirs of (technological) knowledge that are accessible to firms that operate in such countries, affecting their breakthrough inventions and profitability.

Finally, we also control for time (year) effects. All the variables of the model are time variant with the following exceptions: technological opportunities, number of countries of operation, product diversity, and number of patent-generating subsidiaries. Monetary-based values are expressed in thousands of GBP (deflated).

\section{Model and Estimation Method}

Breakthrough inventions, profitability, and invention activities are likely to be endogenous. Put differently, it is not clear whether the invention activity drives breakthrough inventions and profitability or vice versa. In addition, there might be unobserved firm-specific factors influencing both breakthrough inventions, profitability and the development of inventions (e.g., a firm's technological capabilities). Ignoring potential endogeneity might lead to spurious relationships between MNE breakthrough inventions and profitability and the four development activities we are studying. To confront these issues, we follow previous studies (Golovko \& Valentini, 2011; Lockett, Wiklund, Davidsson, \& Girma, 2011) and, as recommended by Meyer, Witteloostuijn Van and Beugelsdijk (2017), apply a method that provides instrumental variables, that is, the widely-adopted System General Method of Moments (GMM-SYS).

The GMM-SYS estimator relies on a system of two equations, the original and the level equation which applies first differences of independent and endogenous variables instrumented by themselves, i.e., by the lags of their first differences (Roodman, 2009). GMM-SYS is particularly appropriate for large cross-section data that involve shorter time periods (Belderbos, Lokshin, \& Sadowski, 2015; Liu, Lu, Filatotchev, Buck, \& Wright, 2010). Because it solves for unobserved heterogeneity and simultaneity, it was found to be superior to other panel data methods such as fixed and random effects (Blundell $\&$ Bond, 2000; Wooldridge, 2009). The following models are tested:
Breakthough inventions $_{i t}=\beta_{0}+\beta_{1}$ Breakthough inventions $_{i t-1}$

$+\beta_{2}$ Within Country Internal $_{\text {it }}$

$+\beta_{3}$ Within Country Collaborative

$+\beta_{4}$ Cross Country Internal ${ }_{i t}$

$+\beta_{5}$ Cross Country Collaborative $_{i t}$

$+\phi\left(X_{i t} \beta\right)+\Omega\left(X_{I} \beta\right)+v_{i t}$

where Breakthough inventions $(R O A)_{i t}$ is the dependent, $\quad \beta_{0}$ the intercept, Breakthoughin ventions $(R O A)_{i t-1}$ is the first lag of the dependent and WithinCountryInternal ${ }_{i t}$ WithinCountry Collaborative $_{i t}$ CrossCountryInternal $_{i t}$ and Cross Country Collaborative $e_{i t}$ refer to the key independent variables. For simplicity, $\phi$ represents the time variant control variables $\left(X_{i t}\right)$ vector and $\beta$ the relevant coefficient, while $\Omega$ is the vector representing control variables $\left(X_{I}\right)$ that are time invariant with corresponding $\beta$ coefficients (Number of patentgenerating subsidiaries, Product Diversity, Number of countries in which the MNE operates, Technological opportunities), ${ }^{4}$ and $v_{i t}$ is the error term. Finally, $I$ refers to MNE and $t$ the time period (from 2003 to 2012 for all variables, with the exception of the lagged dependent variable which takes values from 2002 to 2011).

\section{RESULTS}

Table 1 reports summary statistics and correlations. In our dataset, $64 \%$ of the total 46,580 patents have been developed using within-country internal activity, $19 \%$ using within-country collaborative activity, $11 \%$ using cross-country internal, and $6 \%$ using cross-country collaborative invention. The pairwise correlation matrix shows fairly low correlations among the key independent variables (with few exceptions). We estimated the variance inflation factor (VIF) for each variable in our models as well as the mean VIF for each model. The maximum and mean VIFs for each model are below the acceptable cut-off value of 10 (Hair, Black, Babin, \& Anderson, 2010).

Table 2 reports the results of the GMM-SYS regression analysis. ${ }^{5}$ Models 1 and 3 report the baseline model for each dependent variable, while Models 2 and 4 test the hypothesized relationships. There was no significant autocorrelation in the models, and the difference-in-Hansen tests of the exogeneity of instrument subsets confirmed that the instruments are adequate (Roodman, 2009). Additionally, Wald tests for all variables were 
performed, which supported the suitability of the models (Roodman, 2009).

Hypothesis 1 predicts that cross-country internal invention and within-country collaborative invention increase the development of breakthrough inventions in MNEs more than within-country internal and cross-country collaborative invention. The results (Model 2) show that the coefficient for cross-country internal invention is positive and statistically significant $(\beta=0.011, p=0.000,95 \%$ confidence interval $(\mathrm{CI})=0.008 / 0.014)$. Likewise, the coefficient for within-country collaborative invention is positive and significant $(\beta=0.008$, $p=0.000,95 \%$ confidence interval $(\mathrm{CI})=0.004 /$ 0.012). In contrast, the coefficient for cross-country collaborative invention is positive but insignificant $(\beta=0.001, p=0.252,95 \% \mathrm{CI}=-0.000 / 0.002)$ and the coefficient for within-country internal invention is negative and significant $(\beta=-0.011, p=$ $0.000,95 \% \mathrm{CI}=-0.015 /-0.006)$. Taken together, these results support the predictions of Hypothesis 1 To investigate the difference in the effects, we use the Wald test to examine the null hypothesis that the coefficients are not significantly different (Clogg, Petkova, \& Haritou, 1995; Paternoster, Brame, Mazerolle, \& Piquero, 1998). The $F$ statistic is highly significant $(F=17.58$, Prob $>F=0.000)$, suggesting that the differences in the coefficients cannot be attributed to sampling error (Gould, Pitblado, \& Sribney, 2006).

Hypothesis 2 suggests that cross-country internal and within-country collaborative invention increase MNE profitability more than within-country internal and cross-country collaborative invention. This prediction is supported by the results of Model 4. Specifically, the analysis yields positive and significant coefficients for cross-country internal $(\beta=0.015, p=0.000,95 \% \mathrm{CI}=0.010 / 0.020)$ and within-country collaborative invention $(\beta=0.016$, $p=0.000,95 \% \mathrm{CI}=0.007 / 0.024)$, while withincountry internal $(\beta=-0.016, p=0.001,95 \% \mathrm{CI}=-$ $0.024 /-0.007)$ and cross-country collaborative invention have a negative and significant effect on ROA $(\beta=-0.006, p=0.002,95 \% \mathrm{CI}=-0.009$ / - 0.002). Furthermore, the Wald test yields a significant $F$ statistic $(F=11.14$, Prob $>F=0.000)$, indicating that the differences in the coefficients are statistically significant. ${ }^{6}$

\section{Additional Analyses: The Roles of Experience and Institutions}

We conducted several additional analyses to complement our main analysis. First, a key question that comes to the forefront is why do MNEs engage in within-country internal or cross-country collaborative invention if the two activities are inferior to within-country collaborative and cross-country internal invention, both in terms of breakthrough inventions and profitability. A potential explanation might be that MNEs engage in these activities to increase their overall inventive output (i.e., the number of inventions in their portfolio). To put this view to the test, we ran a new model using patent output ${ }^{7}$ as an alternative dependent variable.

The results of Model 1 in Table 3 show that within-country internal and cross-country collaborative invention activities have a positive effect on the volume of inventions (patent output). Withincountry collaborative and cross-country internal inventions are negatively associated with patent output, with the effect for cross-country internal being significant $(p=0.013)$. Given that patent output is a measure that can be easily observed by managers (while the future impact of inventions and their profitability potential are difficult to predict), these results suggest that MNE managers decide to pursue within-country internal and crosscountry external activities as a way of increasing the size of the MNE's invention portfolio. However, as patent output does not reflect the impact and value of each invention (Lerner, 1994; Trajtenberg, 1990), it accounts poorly for the revenues MNEs can generate from their inventions.

Another important consideration is whether the experience of MNEs in developing inventions in specific countries influences the main results. To examine this possibility, we developed a measure of country experience for each MNE. This measure is weighted according to each MNE's distribution of invention across countries with the highest inventive activity, and is measured as the repeated development of inventions in specific countries, based on inventor location data. We then interacted country experience with the main independent variables. These new results, which are reported in Models 2 and 3 in Table 3, are consistent with the initial results reported in Table 2, but also show that country experience makes crosscountry internal and within-country collaborative invention activities even more beneficial.

Likewise, we examined whether the main results are influenced by the experience that each MNE has in developing inventions with specific partners. To do so, we developed a measure of collaboration experience for each MNE. This measure is estimated 


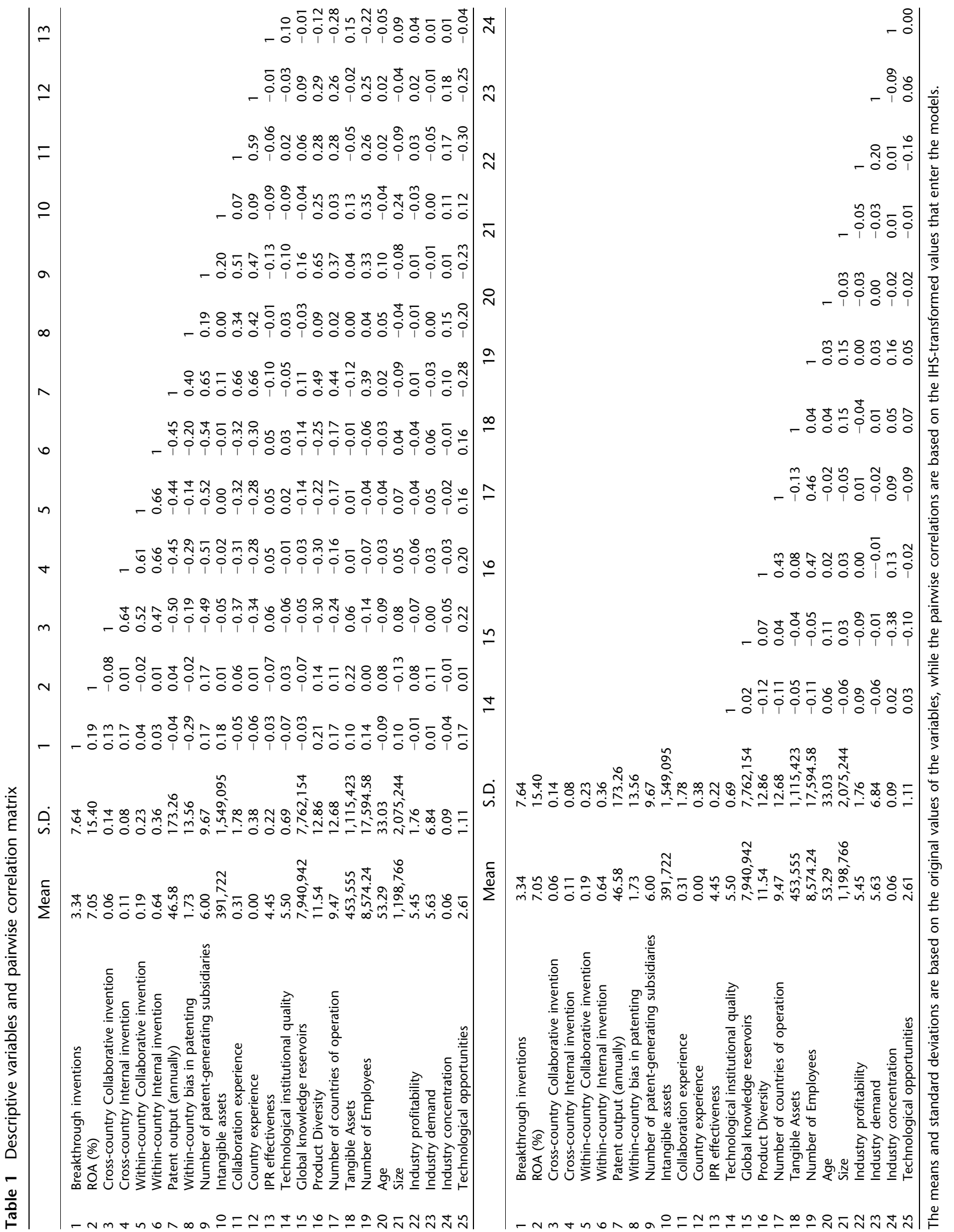


as the repeated development of inventions with specific partners and is weighted according to each MNE's distribution of invention across countries with the highest inventive activity, based on applicants' names data. Models 4 and 5 in Table 3 interact this measure with the main independent variables. These results are, once again, similar to the initial ones and in some cases are even stronger. In addition, corroborating our conceptual framework, the interaction coefficients also show that when MNEs gain experience in developing inventions with specific partners, the effectiveness of the within-country collaborative and cross-country internal invention activities in enhancing breakthrough inventions and profitability becomes stronger.

Finally, we examined whether the quality of technological institutions in the countries where MNEs develop their inventions influence the findings. To capture the quality of such institutions, we used the technology component from the Global Competitiveness Index (GCI-Tech) that captures the progress of technological institutions in each country (Porter, Sala-I-Martin, Lopez-Carlos, \& Schwab, 2004). Such indices have been used widely in prior studies on MNE performance (Goerzen \& Beamish, 2003). Following such studies, we developed the variable 'Technological Institutional Quality' for each MNE which is the weighted average of the GCI-Tech institutional index for the countries in which each MNE develops technology. Models 6 and 7 in Table 3 interact this measure of technological institutional quality with the four invention activities. Once again, the hypothesized effects are confirmed. Interestingly, however, the interactions of cross-country collaborative and within-country internal invention with the quality of technological institutions are positive (but insignificant for breakthrough inventions), while the corresponding interactions of cross-country internal and within-country collaborative invention are negative. These results indicate that the performance gaps between the different invention activities in terms of breakthrough inventions and profitability are sustained but become smaller when technological institutional quality is higher.

\section{Robustness Tests}

Table 4 reports the results for several additional tests that explore how robust the main results are (some results are not reported due to space restrictions). First, we checked the sensitivity of the main results to different measures of profitability; namely, return on capital employed (ROCE) and profit margin. ROCE captures how well a firm is using its capital, while profit margin is the ratio of net operating profit to sales (Richard, Devinney, Yip, \& Johnson, 2009). The new results are consistent with the main results and support the hypotheses (see Models 1 and 2 in Table 4).

Furthermore, we checked whether invention activities have lagged effects on breakthrough innovations and ROA for up to three years (columns 3-8). The results are largely consistent with the main results, with lower significance levels observed, and for some independent variables showing a weaker effect. It is noteworthy that, while the effects of cross-country collaborative invention on future breakthrough inventions is positive (in Models 3, 5 and 7), the Wald tests show that they are still significantly lower than the effects of cross-country internal or within-country collaborative invention activities. Hence, they are still consistent with the predictions of Hypothesis 1.

In addition, although R\&D may influence firm performance (Filatotchev \& Piesse, 2009), we did not include R\&D in the main models in Table 2 to avoid reducing the number of observations in the sample due to missing observations. The results in Models 9 and 10 suggest that the inclusion of R\&D intensity does not impact the main hypothesized effects. Additionally, we checked the sensitivity of the results to the use of alternative estimators using random effects (RE) (based on the Hausman test favoring RE). These results were consistent with the results reported in Table 2.

We have also checked for outliers using the Cox's (2017) extremes command, and for leverage points using the Hosmer and Lemeshow post-estimation (see Verardi \& Croux, 2009). After excluding outliers with high leverage, the results remain consistent with the main results. Moreover, the models presented in Table 2 include measures of industry demand and industry concentration that have been estimated for the UK. We re-ran the main regressions after estimating industry demand and industry concentration globally (given that MNEs in our sample operate in multiple countries). The new results remain consistent with those presented in Table 2.

Furthermore, prior research has recognized that internal MNE networks may establish external networks with other organizations to improve the use and generation of technological knowledge 
1436

Table 2 Regression results using GMM (dependent variables: Breakthrough inventions and ROA)

\begin{tabular}{|c|c|c|c|c|}
\hline & $(1)$ & $(2)$ & (3) & (4) \\
\hline & Breakthrough inventions & Breakthrough inventions & ROA & ROA \\
\hline \multicolumn{5}{|l|}{ Independent variables } \\
\hline Cross-country collaborative invention & & $\begin{array}{l}0.001 \\
(0.001) \\
{[0.252]}\end{array}$ & & $\begin{array}{l}-0.006 \\
(0.002) \\
{[0.002]}\end{array}$ \\
\hline Cross-country Internal invention & & $\begin{array}{l}0.011 \\
(0.002) \\
{[0.000]}\end{array}$ & & $\begin{array}{l}0.015 \\
(0.002) \\
{[0.000]}\end{array}$ \\
\hline Within-country Collaborative invention & & $\begin{array}{l}0.008 \\
(0.002) \\
{[0.000]}\end{array}$ & & $\begin{array}{l}0.016 \\
(0.004) \\
{[0.000]}\end{array}$ \\
\hline Within-country Internal invention & & $\begin{array}{l}-0.011 \\
(0.002) \\
{[0.000]}\end{array}$ & & $\begin{array}{l}-0.016 \\
(0.004) \\
{[0.001]}\end{array}$ \\
\hline \multicolumn{5}{|l|}{ Control variables } \\
\hline Dependent variable $(t-1)$ & $\begin{array}{l}0.049 \\
(0.006) \\
{[0.000]}\end{array}$ & $\begin{array}{l}0.044 \\
(0.007) \\
{[0.000]}\end{array}$ & $\begin{array}{l}0.364 \\
(0.011) \\
{[0.000]}\end{array}$ & $\begin{array}{l}0.359 \\
(0.014) \\
{[0.000]}\end{array}$ \\
\hline Patent output (annually) & $\begin{array}{l}-0.078 \\
(0.014) \\
{[0.000]}\end{array}$ & $\begin{array}{l}-0.102 \\
(0.019) \\
{[0.000]}\end{array}$ & $\begin{array}{l}-0.045 \\
(0.024) \\
{[0.063]}\end{array}$ & $\begin{array}{l}-0.039 \\
(0.028) \\
{[0.169]}\end{array}$ \\
\hline Within-country bias in patenting & $\begin{array}{l}-0.240 \\
(0.027) \\
{[0.000]}\end{array}$ & $\begin{array}{l}-0.213 \\
(0.028) \\
{[0.000]}\end{array}$ & $\begin{array}{l}0.072 \\
(0.054) \\
{[0.187]}\end{array}$ & $\begin{array}{l}0.059 \\
(0.055) \\
{[0.285]}\end{array}$ \\
\hline Number of patent-generating subsidiaries & $\begin{array}{l}0.464 \\
(0.109) \\
{[0.000]}\end{array}$ & $\begin{array}{l}0.531 \\
(0.160) \\
{[0.001]}\end{array}$ & $\begin{array}{l}1.196 \\
(0.170) \\
{[0.000]}\end{array}$ & $\begin{array}{l}1.376 \\
(0.175) \\
{[0.000]}\end{array}$ \\
\hline Intangible assets & $\begin{array}{l}0.040 \\
(0.006) \\
{[0.000]}\end{array}$ & $\begin{array}{l}0.037 \\
(0.006) \\
{[0.000]}\end{array}$ & $\begin{array}{l}-0.031 \\
(0.019) \\
{[0.101]}\end{array}$ & $\begin{array}{l}-0.031 \\
(0.027) \\
{[0.264]}\end{array}$ \\
\hline IPR effectiveness & $\begin{array}{l}-1.050 \\
(1.079) \\
{[0.333]}\end{array}$ & $\begin{array}{l}-1.187 \\
(1.037) \\
{[0.255]}\end{array}$ & $\begin{array}{l}-6.099 \\
(2.151) \\
{[0.006]}\end{array}$ & $\begin{array}{l}-1.904 \\
(2.684) \\
{[0.480]}\end{array}$ \\
\hline Global knowledge reservoirs & $\begin{array}{l}-0.043 \\
(0.059) \\
{[0.467]}\end{array}$ & $\begin{array}{l}-0.072 \\
(0.052) \\
{[0.170]}\end{array}$ & $\begin{array}{l}0.331 \\
(0.118) \\
{[0.006]}\end{array}$ & $\begin{array}{l}0.327 \\
(0.136) \\
{[0.018]}\end{array}$ \\
\hline Product diversity & $\begin{array}{l}0.113 \\
(0.105) \\
{[0.282]}\end{array}$ & $\begin{array}{l}0.199 \\
(0.109) \\
{[0.071]}\end{array}$ & $\begin{array}{l}0.094 \\
(0.086) \\
{[0.275]}\end{array}$ & $\begin{array}{l}0.121 \\
(0.111) \\
{[0.276]}\end{array}$ \\
\hline Number of countries of operation & $\begin{array}{l}0.113 \\
(0.057) \\
{[0.049]}\end{array}$ & $\begin{array}{l}0.114 \\
(0.056) \\
{[0.044]}\end{array}$ & $\begin{array}{l}0.008 \\
(0.076) \\
{[0.915]}\end{array}$ & $\begin{array}{l}0.058 \\
(0.092) \\
{[0.531]}\end{array}$ \\
\hline Tangible assets & $\begin{array}{l}0.006 \\
(0.002) \\
{[0.002]}\end{array}$ & $\begin{array}{l}0.001 \\
(0.003) \\
{[0.646]}\end{array}$ & $\begin{array}{l}0.058 \\
(0.004) \\
{[0.000]}\end{array}$ & $\begin{array}{l}0.052 \\
(0.004) \\
{[0.000]}\end{array}$ \\
\hline Number of employees & $\begin{array}{l}-0.058 \\
(0.034) \\
{[0.086]}\end{array}$ & $\begin{array}{l}-0.107 \\
(0.046) \\
{[0.023]}\end{array}$ & $\begin{array}{l}-0.757 \\
(0.099) \\
{[0.000]}\end{array}$ & $\begin{array}{l}-0.925 \\
(0.113) \\
{[0.000]}\end{array}$ \\
\hline Age & $\begin{array}{l}-0.245 \\
(0.063) \\
{[0.000]}\end{array}$ & $\begin{array}{l}-0.314 \\
(0.065) \\
{[0.000]}\end{array}$ & $\begin{array}{l}-0.459 \\
(0.082) \\
{[0.000]}\end{array}$ & $\begin{array}{l}-0.461 \\
(0.088) \\
{[0.000]}\end{array}$ \\
\hline Size & $\begin{array}{l}0.021 \\
(0.004) \\
{[0.000]}\end{array}$ & $\begin{array}{l}0.012 \\
(0.006) \\
{[0.049]}\end{array}$ & $\begin{array}{l}-0.036 \\
(0.008) \\
{[0.000]}\end{array}$ & $\begin{array}{l}-0.037 \\
(0.012) \\
{[0.002]}\end{array}$ \\
\hline Industry profitability & $\begin{array}{l}-0.036 \\
(0.028) \\
{[0.196]}\end{array}$ & $\begin{array}{l}-0.029 \\
(0.031) \\
{[0.358]}\end{array}$ & $\begin{array}{l}0.176 \\
(0.169) \\
{[0.302]}\end{array}$ & $\begin{array}{l}0.380 \\
(0.241) \\
{[0.118]}\end{array}$ \\
\hline Industry demand & $\begin{array}{l}0.016 \\
(0.005) \\
{[0.002]}\end{array}$ & $\begin{array}{l}0.013 \\
(0.006) \\
{[0.024]}\end{array}$ & $\begin{array}{l}0.079 \\
(0.021) \\
{[0.000]}\end{array}$ & $\begin{array}{l}0.078 \\
(0.023) \\
{[0.001]}\end{array}$ \\
\hline Industry concentration & $\begin{array}{l}0.493 \\
(0.659) \\
{[0.456]}\end{array}$ & $\begin{array}{l}0.894 \\
(0.707) \\
{[0.209]}\end{array}$ & $\begin{array}{l}6.749 \\
(2.392) \\
{[0.006]}\end{array}$ & $\begin{array}{l}6.411 \\
(2.438) \\
{[0.010]}\end{array}$ \\
\hline Technological opportunities & $\begin{array}{l}0.777 \\
(0.173) \\
{[0.000]}\end{array}$ & $\begin{array}{l}0.614 \\
(0.200) \\
{[0.003]}\end{array}$ & $\begin{array}{l}1.213 \\
(0.297) \\
{[0.000]}\end{array}$ & $\begin{array}{l}1.183 \\
(0.296) \\
{[0.000]}\end{array}$ \\
\hline Industry dummies & YES & YES & YES & YES \\
\hline Year dummies & YES & YES & YES & YES \\
\hline$F$ & 375.05 & 262.60 & 1424.42 & 1111.31 \\
\hline$p>F$ & 0.000 & 0.000 & 0.000 & 0.000 \\
\hline$n$ & 982 & 982 & 982 & 982 \\
\hline
\end{tabular}

Standard errors in parentheses and $p$ values in brackets. The number of observations is reduced due to missing values 
(Chen et al., 2019; Ivarsson, 2002; Santangelo et al., 2016). Such networks may be complementary to each other (Castellani \& Zanfei, 2006; De Beule \& Van Beveren, 2019; Phene \& Tallman, 2018). Applying this view to our study implies that some invention activities may complement (or substitute) one another. To test this argument, we interacted the different activities with each other. The addition of such interactions does not change the key results for the hypotheses.

When ROA is used as the dependent variable, the interaction between cross-country collaborative and cross-country internal invention activities yields a positive but very small coefficient $(\beta=$ $0.0004, p=0.000)$, suggesting that these two activities complement each other. The remaining interactions yield negative coefficients, and with lower coefficient size and significance levels than the main effects. For breakthrough inventions, the interactions are either negative and significant with the coefficients being much smaller than the main effects (such as in the case of the interaction between cross-country and within-country collaborative technology development, $\beta=0.0003$, $p=0.000$ ), or are insignificant. Hence, we conclude that complementary and substitution effects exist, but are not particularly strong compared to the main effects.

Finally, although our analysis focuses on organizational and geographic boundaries (Phene et al., 2006; Rosenkopf \& Nerkar, 2001), we also controlled for the technological boundary of firm knowledge. To do so, we collected additional data on patent classes for a sample of 26,173 patents (limited to those applied to the EPO by the MNEs and their subsidiaries during 2003-2012, downloaded using the OECD IP database). Following prior studies (Scalera et al., 2018), we developed a proxy for Technological Scope, the average number of unique two-digit technological classes to which a patent in the MNE's patent portfolio is assigned to (by year). The findings for the hypotheses, when this variable is included, are consistent with the main models.

\section{DISCUSSION AND CONCLUSIONS}

\section{Theoretical Contributions and Managerial Implications}

The forces of global competition require MNEs to organize their technological activities in the most optimal way, both geographically and organizationally (Contractor et al., 2010; Martínez-Noya \& Narula, 2018; Robertson \& Gatignon, 1998; Zanfei, 2000). Although MNEs simultaneously engage in both internal and collaborative inventive activities within and across countries, the profitability implications of combining these activities are not well understood. The model that is proposed in this study addresses this issue and thereby complements extant IB perspectives in a number of ways.

First, internalization theory and the knowledgebased view postulate that the competitive advantages of MNEs lie in creating, transferring, and exploiting a repository of technologies across multiple countries (Buckley \& Casson, 1976; Gupta \& Govindarajan, 1994; Kogut \& Zander, 1993; Rugman, 1981). Although prior perspectives have been fruitful in explaining how MNEs succeed internationally, they see an MNE's success to be driven by a repository of advantageous technological assets without specifying how such a repository can be created to become advantageous, and whether the way in which MNEs develop their technology portfolios is optimal for enhancing their profitability. Prior perspectives are also less concerned with how MNEs simultaneously deal with technologyrelated location and governance decisions (CuervoCazurra et al., 2018). Hence, although the impetus for engaging in different types of invention creation is increasing (Martínez-Noya \& Narula, 2018; West et al., 2014), IB theory offers limited guidance regarding the implications of different invention activities for the profitability of MNEs.

This study proposes an invention-based model that offers insights into this issue. It demonstrates that, in addition to considering the repository of technologies that each MNE possesses, what also matters for explaining MNE profitability is the way in which these technological inventions have been developed across both geographic and organizational boundaries. Analyzing location and governance decisions simultaneously (Contractor et al., 2010; Cuervo-Cazurra et al., 2018) enables this model to show that different invention activities differently affect the likelihood of generating breakthrough inventions, provide MNEs with different revenue and cost advantages, and, in turn, have a different effect on the overall profitability of MNEs. It therefore explains why certain combinations of invention activities along the two boundaries improve MNEs' profitability more than other combinations. The theoretical implication of this premise is that MNE profitability is not merely 
Table 3 Additional analyses

\begin{tabular}{|c|c|c|c|c|c|c|c|}
\hline & $\begin{array}{l}\text { (1) } \\
\text { Patent } \\
\text { output }\end{array}$ & $\begin{array}{l}(2) \\
\text { Breakthrough } \\
\text { inventions }\end{array}$ & $\begin{array}{l}(3) \\
\text { ROA }\end{array}$ & $\begin{array}{l}\text { (4) } \\
\text { Breakthrough } \\
\text { inventions }\end{array}$ & $\begin{array}{l}\text { (5) } \\
\text { ROA }\end{array}$ & $\begin{array}{l}(6) \\
\text { Breakthrough } \\
\text { inventions }\end{array}$ & $\begin{array}{l}\text { (7) } \\
\text { ROA }\end{array}$ \\
\hline \multicolumn{8}{|l|}{ Independent variables } \\
\hline Cross-country collaborative invention & $\begin{array}{l}0.009 \\
(0.001) \\
{[0.000]}\end{array}$ & $\begin{array}{l}0.000 \\
(0.001) \\
{[0.868]}\end{array}$ & $\begin{array}{l}-0.006 \\
(0.002) \\
{[0.015]}\end{array}$ & $\begin{array}{l}0.000 \\
(0.000) \\
{[0.729]}\end{array}$ & $\begin{array}{l}-0.006 \\
(0.003) \\
{[0.020]}\end{array}$ & $\begin{array}{l}-0.069 \\
(0.034) \\
{[0.043]}\end{array}$ & $\begin{array}{l}-0.473 \\
(0.190) \\
{[0.015]}\end{array}$ \\
\hline Cross-country internal invention & $\begin{array}{l}-0.004 \\
(0.002) \\
{[0.013]}\end{array}$ & $\begin{array}{l}0.014 \\
(0.002) \\
{[0.000]}\end{array}$ & $\begin{array}{l}0.014 \\
(0.003) \\
{[0.000]}\end{array}$ & $\begin{array}{l}0.010 \\
(0.001) \\
{[0.000]}\end{array}$ & $\begin{array}{l}0.021 \\
(0.003) \\
{[0.000]}\end{array}$ & $\begin{array}{l}0.081 \\
(0.028) \\
{[0.005]}\end{array}$ & $\begin{array}{l}0.416 \\
(0.116) \\
{[0.001]}\end{array}$ \\
\hline Within-country collaborative invention & $\begin{array}{l}-0.002 \\
(0.002) \\
{[0.524]}\end{array}$ & $\begin{array}{l}0.008 \\
(0.002) \\
{[0.001]}\end{array}$ & $\begin{array}{l}0.010 \\
(0.006) \\
{[0.089]}\end{array}$ & $\begin{array}{l}0.002 \\
(0.001) \\
{[0.041]}\end{array}$ & $\begin{array}{l}0.019 \\
(0.006) \\
{[0.003]}\end{array}$ & $\begin{array}{l}0.091 \\
(0.054) \\
{[0.096]}\end{array}$ & $\begin{array}{l}0.987 \\
(0.251) \\
{[0.000]}\end{array}$ \\
\hline Within-country internal invention & $\begin{array}{l}0.017 \\
(0.003) \\
{[0.000]}\end{array}$ & $\begin{array}{l}-0.015 \\
(0.003) \\
{[0.000]}\end{array}$ & $\begin{array}{l}-0.013 \\
(0.007) \\
{[0.085]}\end{array}$ & $\begin{array}{l}-0.009 \\
(0.001) \\
{[0.000]}\end{array}$ & $\begin{array}{l}-0.020 \\
(0.006) \\
{[0.002]}\end{array}$ & $\begin{array}{l}-0.094 \\
(0.059) \\
{[0.115]}\end{array}$ & $\begin{array}{l}-0.984 \\
(0.255) \\
{[0.000]}\end{array}$ \\
\hline \multicolumn{8}{|l|}{ Interactions } \\
\hline $\begin{array}{l}\text { Cross-country collaborative invention } \times \\
\text { country experience }\end{array}$ & & $\begin{array}{l}-0.002 \\
(0.001) \\
{[0.044]}\end{array}$ & $\begin{array}{l}-0.005 \\
(0.003) \\
{[0.079]}\end{array}$ & & & & \\
\hline $\begin{array}{l}\text { Cross-country Internal invention } \times \text { country } \\
\text { experience }\end{array}$ & & $\begin{array}{l}0.008 \\
(0.001) \\
{[0.000]}\end{array}$ & $\begin{array}{l}0.006 \\
(0.004) \\
{[0.097]}\end{array}$ & & & & \\
\hline $\begin{array}{l}\text { Within-country collaborative invention } \times \\
\text { country experience }\end{array}$ & & $\begin{array}{l}0.009 \\
(0.002) \\
{[0.000]}\end{array}$ & $\begin{array}{l}0.024 \\
(0.005) \\
{[0.000]}\end{array}$ & & & & \\
\hline $\begin{array}{l}\text { Within-country internal invention } \times \text { country } \\
\text { experience }\end{array}$ & & $\begin{array}{l}-0.017 \\
(0.003) \\
{[0.000]}\end{array}$ & $\begin{array}{l}-0.023 \\
(0.006) \\
{[0.000]}\end{array}$ & & & & \\
\hline $\begin{array}{l}\text { Cross-country collaborative invention } \times \\
\text { collaboration experience }\end{array}$ & & & & $\begin{array}{l}-0.002 \\
(0.001) \\
{[0.024]}\end{array}$ & $\begin{array}{l}-0.011 \\
(0.004) \\
{[0.012]}\end{array}$ & & \\
\hline $\begin{array}{l}\text { Cross-country Internal invention } \times \\
\text { collaboration experience }\end{array}$ & & & & $\begin{array}{l}0.006 \\
(0.001) \\
{[0.000]}\end{array}$ & $\begin{array}{l}0.012 \\
(0.005) \\
{[0.014]}\end{array}$ & & \\
\hline $\begin{array}{l}\text { Within-country collaborative invention } \times \\
\text { collaboration experience }\end{array}$ & & & & $\begin{array}{l}0.002 \\
(0.001) \\
{[0.031]}\end{array}$ & $\begin{array}{l}0.034 \\
(0.005) \\
{[0.000]}\end{array}$ & & \\
\hline $\begin{array}{l}\text { Within-country internal invention } \times \\
\text { collaboration experience }\end{array}$ & & & & $\begin{array}{l}-0.007 \\
(0.002) \\
{[0.000]}\end{array}$ & $\begin{array}{l}-0.031 \\
(0.006) \\
{[0.000]}\end{array}$ & & \\
\hline $\begin{array}{l}\text { Cross-country collaborative invention } \times \text { tech. } \\
\text { inst. quality }\end{array}$ & & & & & & $\begin{array}{l}0.029 \\
(0.014) \\
{[0.043]}\end{array}$ & $\begin{array}{l}0.196 \\
(0.079) \\
{[0.015]}\end{array}$ \\
\hline $\begin{array}{l}\text { Cross-country Internal invention } \times \text { tech. inst. } \\
\text { quality }\end{array}$ & & & & & & $\begin{array}{l}{[-0.031} \\
(0.012) \\
{[0.012]}\end{array}$ & $\begin{array}{l}-0.170 \\
(0.048) \\
{[0.001]}\end{array}$ \\
\hline $\begin{array}{l}\text { Within-country collaborative invention } \times \\
\text { tech. inst. quality }\end{array}$ & & & & & & $\begin{array}{l}-0.038 \\
(0.022) \\
{[0.094]}\end{array}$ & $\begin{array}{l}-0.408 \\
(0.104) \\
{[0.000]}\end{array}$ \\
\hline $\begin{array}{l}\text { Within-country Internal invention } \times \text { tech. } \\
\text { inst. quality }\end{array}$ & & & & & & $\begin{array}{l}0.036 \\
(0.024) \\
{[0.142]}\end{array}$ & $\begin{array}{l}0.407 \\
(0.106) \\
{[0.000]}\end{array}$ \\
\hline Control variables & & & & & & & \\
\hline Dependent variable $t-1$ & $\begin{array}{l}0.873 \\
(0.021) \\
{[0.000]}\end{array}$ & $\begin{array}{l}0.044 \\
(0.005) \\
{[0.000]}\end{array}$ & $\begin{array}{l}0.357 \\
(0.013) \\
{[0.000]}\end{array}$ & $\begin{array}{l}0.679 \\
(0.034) \\
{[0.000]}\end{array}$ & $\begin{array}{l}0.362 \\
(0.015) \\
{[0.000]}\end{array}$ & $\begin{array}{l}0.730 \\
(0.042) \\
{[0.000]}\end{array}$ & $\begin{array}{l}0.371 \\
(0.014) \\
{[0.000]}\end{array}$ \\
\hline Patent output (annually) & & $\begin{array}{l}-0.099 \\
(0.026)\end{array}$ & $\begin{array}{l}-0.061 \\
(0.035)\end{array}$ & $\begin{array}{l}-0.039 \\
(0.015)\end{array}$ & $\begin{array}{l}-0.025 \\
(0.034)\end{array}$ & $\begin{array}{l}-0.048 \\
(0.031)\end{array}$ & $\begin{array}{l}0.009 \\
(0.053)\end{array}$ \\
\hline & & {$[0.000]$} & {$[0.081]$} & {$[0.011]$} & [0.453] & {$[0.118]$} & {$[0.872]$} \\
\hline Within-country bias in patenting & $\begin{array}{l}0.054 \\
(0.021) \\
{[0.012]}\end{array}$ & $\begin{array}{l}-0.221 \\
(0.024) \\
{[0.000]}\end{array}$ & $\begin{array}{l}0.004 \\
(0.057) \\
{[0.938]}\end{array}$ & $\begin{array}{l}-0.105 \\
(0.016) \\
{[0.000]}\end{array}$ & $\begin{array}{l}-0.041 \\
(0.052) \\
{[0.433]}\end{array}$ & $\begin{array}{l}-0.099 \\
(0.019) \\
{[0.000]}\end{array}$ & $\begin{array}{l}0.130 \\
(0.043) \\
{[0.003]}\end{array}$ \\
\hline Number of patent-generating subsidiaries & $\begin{array}{l}0.361 \\
(0.146) \\
{[0.015]}\end{array}$ & $\begin{array}{l}0.630 \\
(0.160) \\
{[0.000]}\end{array}$ & $\begin{array}{l}1.374 \\
(0.191) \\
{[0.000]}\end{array}$ & $\begin{array}{l}0.559 \\
(0.098) \\
{[0.000]}\end{array}$ & $\begin{array}{l}1.589 \\
(0.220) \\
{[0.000]}\end{array}$ & $\begin{array}{l}0.446 \\
(0.093) \\
{[0.000]}\end{array}$ & $\begin{array}{l}0.817 \\
(0.158) \\
{[0.000]}\end{array}$ \\
\hline Intangible assets & $\begin{array}{l}-0.011 \\
(0.012) \\
{[0.343]}\end{array}$ & $\begin{array}{l}0.032 \\
(0.009) \\
{[0.001]}\end{array}$ & $\begin{array}{l}0.012 \\
(0.027) \\
{[0.658]}\end{array}$ & $\begin{array}{l}0.023 \\
(0.006) \\
{[0.001]}\end{array}$ & $\begin{array}{l}0.001 \\
(0.027) \\
{[0.963]}\end{array}$ & $\begin{array}{l}0.024 \\
(0.008) \\
{[0.004]}\end{array}$ & $\begin{array}{l}0.025 \\
(0.031) \\
{[0.424]}\end{array}$ \\
\hline Collaboration experience & & & & $\begin{array}{l}0.059 \\
(0.021) \\
{[0.005]}\end{array}$ & $\begin{array}{l}0.088 \\
(0.051) \\
{[0.086]}\end{array}$ & & \\
\hline
\end{tabular}


Table 3 (Continued)

\begin{tabular}{|c|c|c|c|c|c|c|c|}
\hline & $\begin{array}{l}\text { (1) } \\
\text { Patent } \\
\text { output }\end{array}$ & $\begin{array}{l}(2) \\
\text { Breakthrough } \\
\text { inventions }\end{array}$ & $\begin{array}{l}\text { (3) } \\
\text { ROA }\end{array}$ & $\begin{array}{l}\text { (4) } \\
\text { Breakthrough } \\
\text { inventions }\end{array}$ & $\begin{array}{l}\text { (5) } \\
\text { ROA }\end{array}$ & $\begin{array}{l}(6) \\
\text { Breakthrough } \\
\text { inventions }\end{array}$ & $\begin{array}{l}\text { (7) } \\
\text { ROA }\end{array}$ \\
\hline Country experience & & $\begin{array}{l}-0.041 \\
(0.033) \\
{[0.222]}\end{array}$ & $\begin{array}{l}-0.001 \\
(0.051) \\
{[0.985]}\end{array}$ & & & & \\
\hline IPR effectiveness & $\begin{array}{l}-1.752 \\
(1.840) \\
{[0.343]}\end{array}$ & $\begin{array}{l}-0.745 \\
(1.324) \\
{[0.575]}\end{array}$ & $\begin{array}{l}-4.360 \\
(2.813) \\
{[0.124]}\end{array}$ & $\begin{array}{l}-0.699 \\
(0.647) \\
{[0.282]}\end{array}$ & $\begin{array}{l}-2.639 \\
(3.498) \\
{[0.452]}\end{array}$ & $\begin{array}{l}0.168 \\
(0.607) \\
{[0.782]}\end{array}$ & $\begin{array}{l}-4.115 \\
(2.928) \\
{[0.163]}\end{array}$ \\
\hline Technological institutional quality & & & & & & $\begin{array}{l}0.113 \\
(0.220) \\
{[0.608]}\end{array}$ & $\begin{array}{l}-0.774 \\
(1.820) \\
{[0.672]}\end{array}$ \\
\hline Global knowledge reservoirs & $\begin{array}{l}-0.098 \\
(0.109) \\
{[0.372]}\end{array}$ & $\begin{array}{l}-0.091 \\
(0.075) \\
{[0.230]}\end{array}$ & $\begin{array}{l}0.299 \\
(0.152) \\
{[0.052]}\end{array}$ & $\begin{array}{l}-0.232 \\
(0.046) \\
{[0.000]}\end{array}$ & $\begin{array}{l}0.426 \\
(0.181) \\
{[0.020]}\end{array}$ & $\begin{array}{l}-0.214 \\
(0.048) \\
{[0.000]}\end{array}$ & $\begin{array}{l}0.278 \\
(0.140) \\
{[0.050]}\end{array}$ \\
\hline Product diversity & $\begin{array}{l}-0.016 \\
(0.059) \\
{[0.792]}\end{array}$ & $\begin{array}{l}0.186 \\
(0.108) \\
{[0.089]}\end{array}$ & $\begin{array}{l}0.067 \\
(0.102) \\
{[0.513]}\end{array}$ & $\begin{array}{l}0.074 \\
(0.065) \\
{[0.260]}\end{array}$ & $\begin{array}{l}0.202 \\
(0.126) \\
{[0.112]}\end{array}$ & $\begin{array}{l}-0.007 \\
(0.064) \\
{[0.914]}\end{array}$ & $\begin{array}{l}0.058 \\
(0.124) \\
{[0.643]}\end{array}$ \\
\hline Number of countries of operation & $\begin{array}{l}0.072 \\
(0.053) \\
{[0.180]}\end{array}$ & $\begin{array}{l}0.115 \\
(0.059) \\
{[0.054]}\end{array}$ & $\begin{array}{l}0.145 \\
(0.103) \\
{[0.161]}\end{array}$ & $\begin{array}{l}0.030 \\
(0.035) \\
{[0.390]}\end{array}$ & $\begin{array}{l}0.155 \\
(0.125) \\
{[0.218]}\end{array}$ & $\begin{array}{l}0.062 \\
(0.040) \\
{[0.130]}\end{array}$ & $\begin{array}{l}0.175 \\
(0.104) \\
{[0.096]}\end{array}$ \\
\hline Tangible assets & $\begin{array}{l}-0.006 \\
(0.004) \\
{[0.079]}\end{array}$ & $\begin{array}{l}0.003 \\
(0.004) \\
{[0.397]}\end{array}$ & $\begin{array}{l}0.056 \\
(0.007) \\
{[0.000]}\end{array}$ & $\begin{array}{l}0.002 \\
(0.002) \\
{[0.213]}\end{array}$ & $\begin{array}{l}0.052 \\
(0.005) \\
{[0.000]}\end{array}$ & $\begin{array}{l}0.003 \\
(0.002) \\
{[0.202]}\end{array}$ & $\begin{array}{l}0.073 \\
(0.009) \\
{[0.000]}\end{array}$ \\
\hline Number of employees & $\begin{array}{l}-0.140 \\
(0.061) \\
{[0.024]}\end{array}$ & $\begin{array}{l}-0.132 \\
(0.066) \\
{[0.047]}\end{array}$ & $\begin{array}{l}-1.014 \\
(0.157) \\
{[0.000]}\end{array}$ & $\begin{array}{l}-0.139 \\
(0.035) \\
{[0.000]}\end{array}$ & $\begin{array}{l}-1.324 \\
(0.189) \\
{[0.000]}\end{array}$ & $\begin{array}{l}-0.053 \\
(0.036) \\
{[0.148]}\end{array}$ & $\begin{array}{l}-0.666 \\
(0.127) \\
{[0.000]}\end{array}$ \\
\hline Age & $\begin{array}{l}-0.107 \\
(0.081) \\
{[0.188]}\end{array}$ & $\begin{array}{l}-0.276 \\
(0.083) \\
{[0.001]}\end{array}$ & $\begin{array}{l}-0.452 \\
(0.096) \\
{[0.000]}\end{array}$ & $\begin{array}{l}-0.157 \\
(0.049) \\
{[0.002]}\end{array}$ & $\begin{array}{l}-0.485 \\
(0.117) \\
{[0.000]}\end{array}$ & $\begin{array}{l}-0.123 \\
(0.043) \\
{[0.005]}\end{array}$ & $\begin{array}{l}-0.279 \\
(0.082) \\
{[0.001]}\end{array}$ \\
\hline Size & $\begin{array}{l}-0.010 \\
(0.007) \\
{[0.148]}\end{array}$ & $\begin{array}{l}0.016 \\
(0.009) \\
{[0.073]}\end{array}$ & $\begin{array}{l}-0.034 \\
(0.014) \\
{[0.022]}\end{array}$ & $\begin{array}{l}0.012 \\
(0.005) \\
{[0.017]}\end{array}$ & $\begin{array}{l}-0.042 \\
(0.012) \\
{[0.001]}\end{array}$ & $\begin{array}{l}0.015 \\
(0.005) \\
{[0.004]}\end{array}$ & $\begin{array}{l}-0.034 \\
(0.012) \\
{[0.006]}\end{array}$ \\
\hline Industry profitability & $\begin{array}{l}-0.034 \\
(0.055) \\
{[0.536]}\end{array}$ & $\begin{array}{l}0.017 \\
(0.035) \\
{[0.635]}\end{array}$ & $\begin{array}{l}0.332 \\
(0.259) \\
{[0.202]}\end{array}$ & $\begin{array}{l}-0.008 \\
(0.026) \\
{[0.749]}\end{array}$ & $\begin{array}{l}0.320 \\
(0.235) \\
{[0.177]}\end{array}$ & $\begin{array}{l}-0.062 \\
(0.030) \\
{[0.041]}\end{array}$ & $\begin{array}{l}-0.014 \\
(0.182) \\
{[0.937]}\end{array}$ \\
\hline Industry demand & $\begin{array}{l}-0.004 \\
(0.010) \\
{[0.686]}\end{array}$ & $\begin{array}{l}0.000 \\
(0.007) \\
{[0.980]}\end{array}$ & $\begin{array}{l}0.048 \\
(0.025) \\
{[0.062]}\end{array}$ & $\begin{array}{l}0.009 \\
(0.004) \\
{[0.011]}\end{array}$ & $\begin{array}{l}0.062 \\
(0.025) \\
{[0.017]}\end{array}$ & $\begin{array}{l}0.006 \\
(0.004) \\
{[0.196]}\end{array}$ & $\begin{array}{l}0.088 \\
(0.020) \\
{[0.000]}\end{array}$ \\
\hline Industry concentration & $\begin{array}{l}0.082 \\
(2.074) \\
{[0.969]}\end{array}$ & $\begin{array}{l}1.072 \\
(0.832) \\
{[0.200]}\end{array}$ & $\begin{array}{l}5.144 \\
(2.859) \\
{[0.075]}\end{array}$ & $\begin{array}{l}0.660 \\
(0.518) \\
{[0.206]}\end{array}$ & $\begin{array}{l}8.132 \\
(2.572) \\
{[0.002]}\end{array}$ & $\begin{array}{l}0.693 \\
(0.521) \\
{[0.187]}\end{array}$ & $\begin{array}{l}0.681 \\
(2.419) \\
{[0.779]}\end{array}$ \\
\hline Technological opportunities & $\begin{array}{l}-0.359 \\
(0.402) \\
{[0.375]}\end{array}$ & $\begin{array}{l}0.756 \\
(0.188) \\
{[0.000]}\end{array}$ & $\begin{array}{l}0.937 \\
(0.494) \\
{[0.061]}\end{array}$ & $\begin{array}{l}0.495 \\
(0.141) \\
{[0.001]}\end{array}$ & $\begin{array}{l}1.346 \\
(0.383) \\
{[0.001]}\end{array}$ & $\begin{array}{l}0.454 \\
(0.138) \\
{[0.001]}\end{array}$ & $\begin{array}{l}1.184 \\
(0.461) \\
{[0.012]}\end{array}$ \\
\hline Industry dummies & YES & YES & YES & YES & YES & YES & YES \\
\hline $\begin{array}{l}\text { Year dummies } \\
F\end{array}$ & $\begin{array}{l}\text { YES } \\
1768.20\end{array}$ & $\begin{array}{l}\text { YES } \\
671.81\end{array}$ & $\begin{array}{l}\text { YES } \\
2902.21\end{array}$ & $\begin{array}{l}\text { YES } \\
2662.78\end{array}$ & $\begin{array}{l}\text { YES } \\
882.91\end{array}$ & $\begin{array}{l}\text { YES } \\
363.73\end{array}$ & $\begin{array}{l}\text { YES } \\
1365.48\end{array}$ \\
\hline$p>F$ & 0.000 & 0.000 & 0.000 & 0.000 & 0.000 & 0.000 & 0.000 \\
\hline$n$ & 900 & 882 & 882 & 828 & 982 & 828 & 873 \\
\hline
\end{tabular}

Standard errors in parentheses and $p$ values in brackets. The number of observations is reduced due to missing values

driven by stronger technological endowments but also by the fact that certain ways of developing technological inventions change the propensity of inventions to become impactful (breakthroughs), and, in turn, the value and profits they generate for the MNE.

Second, departing from conceptualizations that predominantly consider the attributes of MNEs or their decisions to conduct R\&D abroad (Berry, 2014; Cantwell \& Mudambi, 2005; Castellani et al., 2013; Narula, 2014) and establish technological alliances (Alcacer et al., 2016; Robertson \&
Gatignon, 1998), this study shifts scholarly attention to the implications of creating inventions in certain ways. An important premise in our framework is that, while the marginal revenues from distributing inventive activities across both the geographic and organizational boundaries increase in a diminishing manner, the corresponding marginal costs of doing so increase exponentially. Because of these differences in how revenues and costs increase, our analysis shows that a 'balanced' approach to invention across the geographic and organizational boundaries contributes the most to 


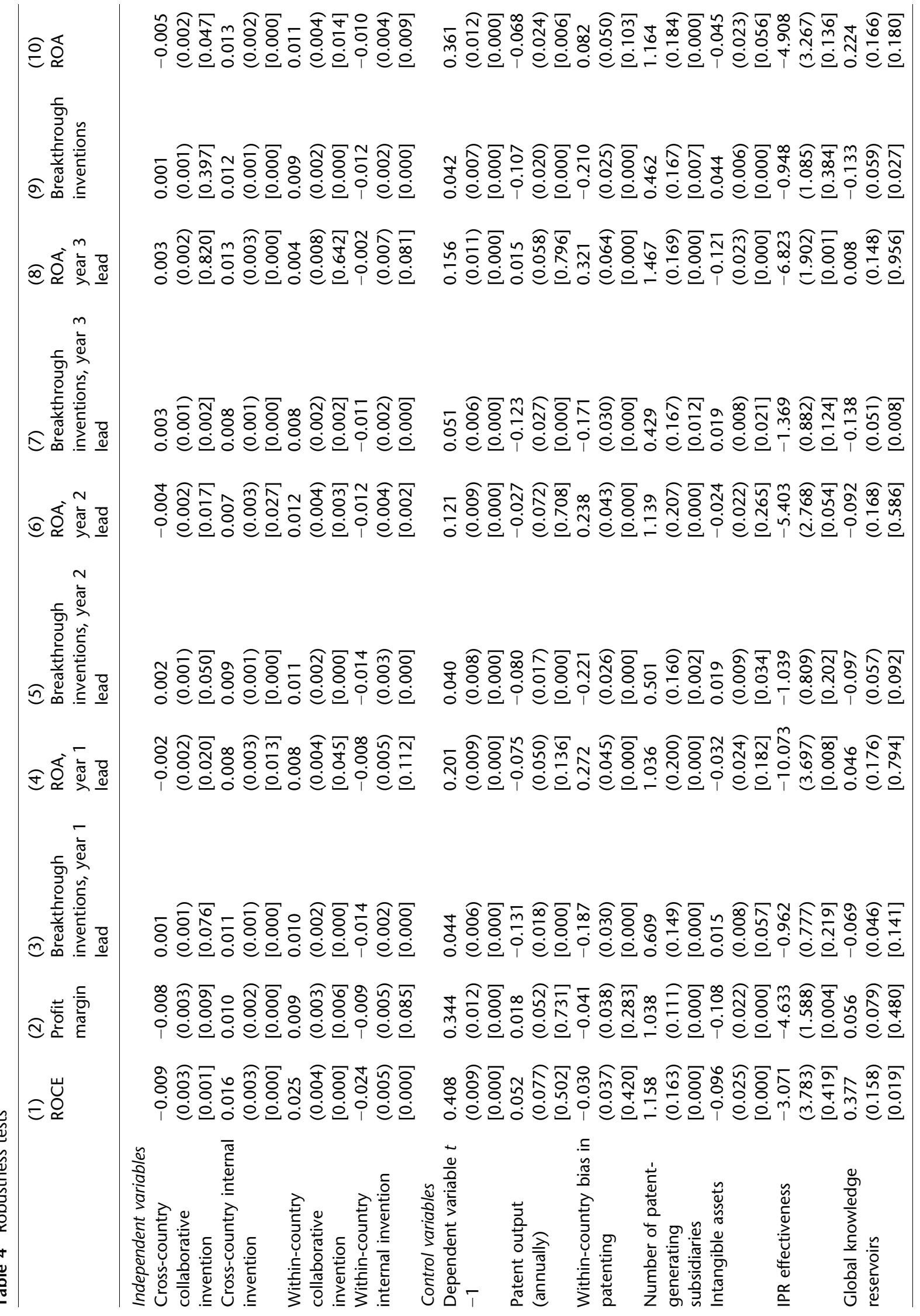




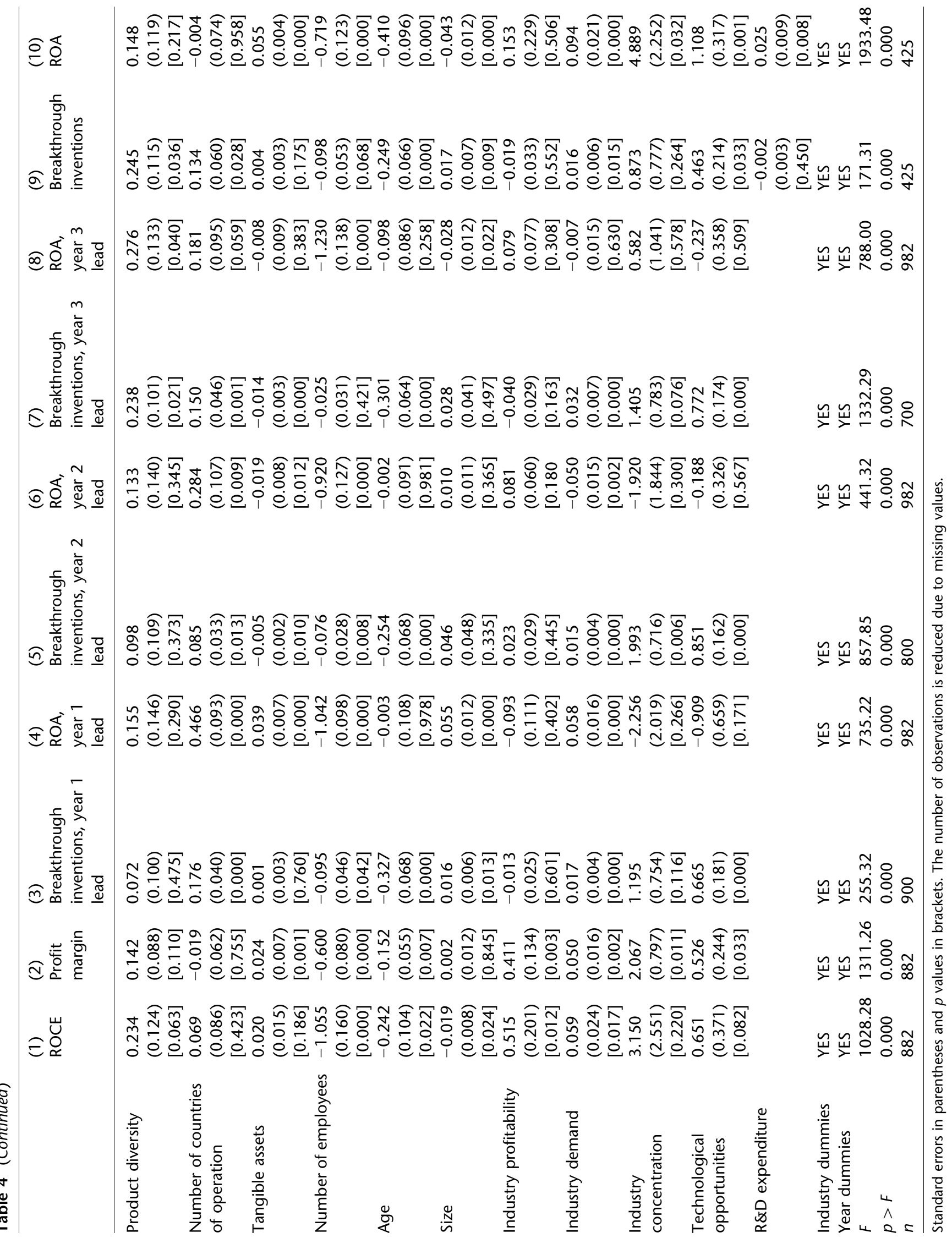


MNE profitability. Two invention activities (namely, cross-country internal and within-country collaborative) achieve such a balance as they distribute the development of inventions on one boundary and concentrate it on the other. These activities are the most profitable because they allow MNEs to keep the costs and complexities of developing inventions to low or moderate levels, while facilitating the absorption, transfer, and combination of diverse knowledge that, in turn, results in valuable breakthrough inventions, greater revenues, and higher profitability.

By contrast, invention activities that are either highly concentrated or highly distributed across the geographic and organizational boundaries are less effective in enhancing MNE profitability. Our analysis shows that a concentrated invention activity (i.e., within-country internal) limits the scope of MNEs' technological knowledge and decreases the likelihood of developing breakthrough inventions, thus eroding revenue generation and profitability. Equally, a distributed invention activity (i.e., crosscountry collaborative) hampers MNE profitability as it increases coordination and monitoring costs exponentially and makes the management of diversity particularly difficult. As a result, crosscountry internal and within-country collaborative invention activities increase the generation of breakthroughs and MNE profitability more than within-country internal and cross-country collaborative invention activities. These insights further extend the knowledge-based view of the firm (Gupta \& Govindarajan, 2000; Kogut \& Zander, 1993; Martin \& Salomon, 2003) by showing that the creation of valuable technological knowledge is facilitated, not only by internalized cross-country invention activities but also by externalized invention activities as long as they are conducted within a country.

In broader terms, the invention-based perspective complements organizational learning perspectives that emphasize the benefits of balancing different activities, including the exploration-exploitation perspective (He \& Wong, 2004; Levinthal \& March, 1993; March, 1991) and research that advocates the need to balance "distant" knowledge search with the geographic origins of knowledge (Phene et al., 2006). The invention-based perspective extends the reasoning of such studies by showing how technological knowledge that is more proximate to that of the MNE in terms of geographic or organizational boundaries (either within-country or internally developed), and technological knowledge that is more distant from that of the MNE in these two boundaries (either cross-country or collaboratively developed), can be successfully combined to develop breakthrough inventions and so increase profitability.

Finally, our analysis has implications for managerial practice suggesting that, for competitive advantage and superior profitability, an MNE must not simply create new technologies, it must create them in an optimal way by simultaneously considering such choices across the geographic and organizational boundaries. As our analysis shows, inventive activity leads to inferior outcomes if it is not organized in the right manner. The model proposed in this paper brings managerial choices to the forefront, suggesting that closer attention should be given to the ways in which specific inventions are developed, rather than merely to $R \& D$ location choices and the existence of alliances. MNEs seeking to profit from their technologies must organize their development in a manner that enhances revenues without increasing the associated costs disproportionally. Our model yields insights into how MNEs can achieve this, predicting that balanced approaches to invention are more profitable than highly concentrated (within-country internal) or highly distributed (cross-country collaborative). This point is particularly salient given that $70 \%$ of the patents in our sample fall in these two categories that are less optimal in generating breakthrough inventions and profits. Hence, a key implication of the study is that an MNE's ability to generate profits from its technological assets will depend primarily on its effectiveness in organizing how such assets are developed.

\section{Limitations and Future Research}

This study can be advanced in several ways. First, we have considered how different invention activities influence MNE profitability and the potential for creating breakthrough inventions, but we have not examined how such activities influence the development of different types of inventions (which may differ in their international applicability and other characteristics) and the strategic role they serve in the specialization of specific units (Alcácer et al., 2016; Cantwell, 2017; Phene \& Tallman, 2018). Although we have examined the role of geographic and collaborative experience and that of institutions, future research can investigate the role of other invention-, firm-, and environmentspecific contingencies, and how these may make 
some invention activities more beneficial than others. Such contingencies, for instance, may include the technological dynamism of each industry and the appropriability conditions in each country (Kafouros et al., 2012; Santangelo et al., 2016). Equally, as the post hoc analyses show that the performance gaps between the different invention activities in terms of breakthrough inventions and profitability become smaller when technological institutional quality increases, environmental and institutional effects should be further explored.

Furthermore, our analysis has focused on the geographic and organizational boundaries of invention, without examining how such development may vary along the technological boundary (e.g., close versus distant knowledge search in different domains; Phene et al., 2006; Rosenkopf \& Nerkar, 2001). Future studies may extend our framework by investigating how invention development combinations that vary in the technological space may affect MNE profitability. An equally useful research avenue would be to examine how the effect of invention activities on MNE profitability is influenced by the relative position of the MNE's home country and other countries where inventions are developed with respect to the global invention frontier (Belderbos et al., 2015).

Another question that is beyond the scope of the current study is how changing the emphasis on specific invention activities over time can affect MNE profitability. Given that MNEs develop routines that support specific invention activities, frequent changes in the emphasis given to specific invention activities may harm profitability. Yet, such changes also highlight MNE efforts to avoid the negative consequences of inertia. An interesting research question in this regard is how MNEs should sequence changes in their portfolio of invention activities along geographic and organizational boundaries.

In conclusion, this study has proposed that the process of creating competitive advantages and generating profits is not simply a function of possessing technological assets but primarily depends on the way in which these assets are developed. In support of this central tenet, the study has developed a perspective that provides insights into how inventive activities can be combined across the organizational and geographic boundaries in ways that increase the propensity of creating breakthrough inventions and enhancing profitability. In showing that the way of developing inventions is an increasingly important unit of analysis and an important source of competitive advantage, the study opens a range of future research avenues for exploring how the ways in which MNEs choose to organize the development of their inventions provide new explanations about the determinants of MNE profitability.

\section{OPEN ACCESS}

This article is licensed under a Creative Commons Attribution 4.0 International License, which permits use, sharing, adaptation, distribution and reproduction in any medium or format, as long as you give appropriate credit to the original author(s) and the source, provide a link to the Creative Commons licence, and indicate if changes were made. The images or other third party material in this article are included in the article's Creative Commons licence, unless indicated otherwise in a credit line to the material. If material is not included in the article's Creative Commons licence and your intended use is not permitted by statutory regulation or exceeds the permitted use, you will need to obtain permission directly from the copyright holder. To view a copy of this licence, visit http://creativecommons.org/licenses/ by $/ 4.0 /$.

\section{NOTES}

${ }^{1}$ In this paper, the term invention refers to proprietary know-how, technologies, and products.

${ }^{2}$ Breakthrough inventions refer to the most used (cited) patents within a technology class.

${ }^{3}$ Park's (2008) indices were complemented with more recent data made available by the author, sourced from: http://fs2.american.edu/wgp/www/

${ }^{4}$ All time invariant data relate to the year 2012 .

${ }^{5}$ With the exception of the dummy and technological opportunities variables, all the other variables went through an inverse hyperbolic sine (IHS) transformation, that allows dealing with some negative ROA values. The results remain the same when we use logs rather than the IHS transformation.

${ }^{6}$ To better understand the size of these effects, we estimated the margins for the minimum and maximum values of the invention activity measures within our dataset. These estimations help us to understand how much the actual values of the dependent variables change because of variations in these activities. For instance, the difference from 
the minimum to maximum values of cross-country internal invention (when calculated as the mean of all other variables) represents an increase of 0.61 points (or around 0.65 percent) in MNEs' breakthrough innovations and 0.77 (or around 0.85 percent) points in MNEs' ROA, while the corresponding increase for within-country collaborative invention is 0.57 (or around 0.62 percent) points in MNEs' breakthrough innovations and 0.77 (or

\section{REFERENCES}

Adler, N., \& Hashai, N. 2007. Knowledge flows and the modelling of the multinational enterprise. Journal of International Business Studies, 38(4): 639-657.

Ahuja, G. 2000. Collaboration networks, structural holes, and innovation: A longitudinal study. Administrative Science Quarterly, 45(3): 425-455.

Alcácer, J., Cantwell, J., \& Piscitello, L. 2016. Internationalization in the information age: A new era for places, firms, and international business networks? Journal of International Business Studies, 47(5): 499-516.

Alcacer, J., \& Oxley, J. 2014. Learning by supplying. Strategic Management Journal, 35(2): 204-223.

Almeida, P. 1996. Knowledge sourcing by foreign multinationals: Patent citation analysis in the US semiconductor industry. Strategic Management Journal, 17(2): 155-165.

Almeida, P., \& Kogut, B. 1999. Localization of knowledge and the mobility of engineers in regional networks. Management Science, 45(7): 905-917.

Almeida, P., \& Phene, A. 2004. Subsidiaries and knowledge creation: The influence of the MNC and host country on innovation. Strategic Management Journal, 25(8-9): 847-864.

Alnuaimi, T., Singh, J., \& George, G. 2012. Not with my own: Long-term effects of cross-country collaboration on subsidiary innovation in emerging economies versus advanced economies. Journal of Economic Geography, 12(5): 943-968.

Anand, J., \& Delios, A. 2002. Absolute and relative resources as determinants of international acquisitions. Strategic Management Journal, 23(2): 119-134.

Arora, A., Belenzon, S., \& Rios, L. A. 2014. Make, buy, organize: The interplay between research, external knowledge, and firm structure. Strategic Management Journal, 35(3): 317-337.

Asmussen, C. G., Pedersen, T., \& Dhanaraj, C. 2009. Hostcountry environment and subsidiary competence: Extending the diamond network model. Journal of International Business Studies, 40(1): 42-57.

Barkema, H. G., Bell, J. H., \& Pennings, J. M. 1996. Foreign entry, cultural barriers, and learning. Strategic Management Journal, 17(2): 151-166.

Belderbos, R., Carree, M., \& Lokshin, B. 2004. Cooperative R\&D and firm performance. Research Policy, 33(10): 1477-1492.

Belderbos, R., Leten, B., \& Suzuki, S. 2013. How global is R\&D? Firm-level determinants of home-country bias in R\&D. Journal of International Business Studies, 44(8): 765-786.

Belderbos, R., Lokshin, B., \& Sadowski, B. 2015. The returns to foreign R\&D. Journal of International Business Studies, 46(4): 491-504.

Berry, H. 2014. Global integration and innovation: Multicountry knowledge generation within MNCs. Strategic Management Journal, 35(6): 869-890.

Blundell, R., \& Bond, S. 2000. GMM estimation with persistent panel data: An application to production functions. Econometric Reviews, 19(3): 321-340.

Borgatti, S. P., Everett, M. G., \& Freeman, L. C. 2002. Ucinet for windows: Software for social network analysis. Analytic Technologies. around 0.85 percent) points in MNEs' ROA. These results point to significant variations across the effects of invention activities, confirming their economic importance.

${ }^{7}$ We use the volume of patents in the year following patent development to account for patent approval processes.

Buckley, P. J., \& Carter, M. J. 2004. A formal analysis of knowledge combination in multinational enterprises. Journal of International Business Studies, 35(5): 371-384.

Buckley, P., \& Casson, M. 1976. The future of the multinational enterprise. Teaneck, NJ: Holmes \& Meier.

Buckley, P. J., \& Casson, M. C. 1998. Analyzing foreign market entry strategies: Extending the internalization approach. Journal of International Business Studies, 29(3): 539-561.

Cantwell, J. 1995. The globalisation of technology: What remains of the product cycle model? Cambridge Journal of Economics, 19(1): 155-155.

Cantwell, J. 2017. Innovation and international business. Industry and Innovation, 24(1): 41-60.

Cantwell, J., \& Mudambi, R. 2005. MNE competence-creating subsidiary mandates. Strategic Management Journal, 26(12): 1109-1128.

Capaldo, A., \& Petruzzelli, A. M. 2011. In search of alliance-level relational capabilities: Balancing innovation value creation and appropriability in R\&D alliances. Scandinavian Journal of Management, 27(3): 273-286.

Cassiman, B., \& Veugelers, R. 2002. R\&D cooperation and spillovers: Some empirical evidence from Belgium. American Economic Review, 92(4): 1169-1184.

Cassiman, B., \& Veugelers, R. 2006. In search of complementarity in innovation strategy: Internal $R \& D$ and external knowledge acquisition. Management Science, 52(1): 68-82.

Castellani, D., Jimenez, A., \& Zanfei, A. 2013. How remote are R\&D labs? Distance factors and international innovative activities. Journal of International Business Studies, 44(7): 649675.

Castellani, D., \& Zanfei, A. 2006. Multinational firms, innovation and productivity. Cheltenham: Edward Elgar.

Chan, W., Hwang, P., \& Burgers, W. P. 1989. Global diversification strategy and corporate profit performance. Strategic Management Journal, 10(1): 45-57.

Chen, K., Zhang, Y., \& Fu, X. 2019. International research collaboration: An emerging domain of innovation studies? Research Policy, 48(1): 149-168.

Chesbrough, H. W. 2006. Open innovation: The new imperative for creating and profiting from technology. Harvard Business Press.

Clogg, C. C., Petkova, E., \& Haritou, A. 1995. Statistical methods for comparing regression coefficients between models. American Journal of Sociology, 100(5): 1261-1293.

Contractor, F. I., Kumar, V., Kundu, S. K., \& Pedersen, T. 2010. Reconceptualizing the firm in a world of outsourcing and offshoring: The organizational and geographical relocation of high-value company functions. Journal of Management Studies, 47(8): 1417-1433.

Corsino, M., Mariani, M., \& Torrisi, S. 2019. Firm strategic behavior and the measurement of knowledge flows with patent citations. Strategic Management Journal, 40(7): 10401069. 
Cox, N. 2017. Extremes: Stata module to list extreme values of a variable. https://econpapers.repec.org/software/bocbocode/ s430801.htm. Accessed 20 January 2020.

Cuervo-Cazurra, A., Nieto, M. J., \& Rodríguez, A. 2018. The impact of R\&D sources on new product development: Sources of funds and the diversity versus control of knowledge debate. Long Range Planning, 51(5): 649-665.

Cummings, J. N., \& Kiesler, S. 2007. Coordination costs and project outcomes in multi-university collaborations. Research Policy, 36(10): 1620-1634.

Dachs, B., \& Pyka, A. 2010. What drives the internationalisation of innovation? Evidence from European patent data. Economics of Innovation and New Technology, 19(1): 71-86.

De Beule, F., \& Van Beveren, I. 2019. Sources of open innovation in foreign subsidiaries: An enriched typology. International Business Review, 28(1): 135-147.

Decarolis, D. M. 2003. Competencies and imitability in the pharmaceutical industry: An analysis of their relationship with firm performance. Journal of Management, 29(1): 27-50.

Decarolis, D. M., \& Deeds, D. L. 1999. The impact of stocks and flows of organizational knowledge on firm performance: An empirical investigation of the biotechnology industry. Strategic Management Journal, 20(10): 953-968.

Delios, A., \& Beamish, P. W. 1999. Geographic scope, product diversification, and the corporate performance of Japanese firms. Strategic Management Journal, 20(8): 711-727.

Delios, A., \& Henisz, W. J. 2003. Political hazards, experience, and sequential entry strategies: The international expansion of Japanese firms, 1980-1998. Strategic Management Journal, 24 (11): 1153-1164.

Derfus, P. J., Maggitti, P. G., Grimm, C. M., \& Smith, K. G. 2008. The Red Queen effect: Competitive actions and firm performance. Academy of Management Journal, 51(1): 61-80.

Doz, Y., Santos, J., \& Williamson, P. 2001. From global to metanational: How companies win in the knowledge economy. Boston: Harvard Business School Press.

Dunning, J. H. 1996. The geographical sources of the competitiveness of firms: Some results of a new survey. University of Reading, Department of Economics.

Feinberg, S. E., \& Gupta, A. K. 2004. Knowledge spillovers and the assignment of R\&D responsibilities to foreign subsidiaries. Strategic Management Journal, 25(8-9): 823-845.

Filatotchev, I., \& Piesse, J. 2009. R\&D, internationalization and growth of newly listed firms: European evidence. Journal of International Business Studies, 40(8): 1260-1276.

Fleming, L., \& Sorenson, O. 2001. Technology as a complex adaptive system: Evidence from patent data. Research Policy, 30(7): 1019-1039.

Fleming, L., \& Sorenson, O. 2004. Science as a map in technological search. Strategic Management Journal, 25(8-9): 909-928.

Frishammar, J., Ericsson, K., \& Patel, P. C. 2015. The dark side of knowledge transfer: Exploring knowledge leakage in joint R\&D projects. Technovation, 41-42: 75-88.

Frost, T. S., \& Zhou, C. 2005. R\&D co-practice and 'reverse'knowledge integration in multinational firms. Journal of International Business Studies, 36(6): 676-687.

Furman, J. L., Porter, M. E., \& Stern, S. 2002. The determinants of national innovative capacity. Research Policy, 31(6): 899933.

Gans, J. S., \& Stern, S. 2003. The product market and the market for "ideas": Commercialization strategies for technology entrepreneurs. Research Policy, 32(2): 333-350.

Ghoshal, S. 1987. Global strategy: An organizing framework. Strategic Management Journal, 8(5): 425-440.

Goerzen, A., \& Beamish, P. W. 2003. Geographic scope and multinational enterprise performance. Strategic Management Journal, 24(13): 1289-1306.

Goerzen, A., \& Beamish, P. W. 2005. The effect of alliance network diversity on multinational enterprise performance. Strategic Management Journal, 26(4): 333-354.
Golovko, E., \& Valentini, G. 2011. Exploring the complementarity between innovation and export for SMEs' growth. Journal of International Business Studies, 42(3): 362-380.

Gould, W., Pitblado, J., \& Sribney, W. 2006. Maximum likelihood estimation with Stata. College Station, TX: Stata.

Griliches, Z. 1998. Patent statistics as economic indicators: A survey. In Z. Griliches (Ed.), $R \& D$ and productivity: The econometric evidence: 287-343. Chiacago: University of Chicago Press.

Grimpe, C., \& Sofka, W. 2009. Search patterns and absorptive capacity: Low-and high-technology sectors in European countries. Research Policy, 38(3): 495-506.

Gulati, R., \& Singh, H. 1998. The architecture of cooperation: Managing coordination costs and appropriation concerns in strategic alliances. Administrative Science Quarterly, 43(4): 781-814.

Gupta, A. K., \& Govindarajan, V. 1994. Organizing for knowledge flows within MNCs. International Business Review, 3(4): 443-457.

Gupta, A. K., \& Govindarajan, V. 2000. Knowledge flows within multinational corporations. Strategic Management Journal, 21 (4): 473-496.

Hagedoorn, J., \& Schakenraad, J. 1994. The effect of strategic technology alliances on company performance. Strategic Management Journal, 15(4): 291-309.

Hair, J. F., Black, W. C., Babin, B. J., \& Anderson, R. E. 2010. Multivariate data analysis with reading. Hoboken, NJ: Prentice Hall.

Hall, R. 1993. A framework linking intangible resources and capabiliites to sustainable competitive advantage. Strategic Management Journal, 14(8): 607-618.

Hawawini, G., Subramanian, V., \& Verdin, P. 2003. Is performance driven by industry-or firm-specific factors? A new look at the evidence. Strategic Management Journal, 24(1): 1-16.

He, Z.-L., \& Wong, P.-K. 2004. Exploration vs exploitation: An empirical test of the ambidexterity hypothesis. Organization Science, 15(4): 481-494.

Hennart, J. F. 1993. Explaining the swollen middle: Why most transactions are a mix of "market" and "hierarchy." Organization Science, 4(4): 529-547.

Hitt, M. A., Hoskisson, R. E., \& Kim, H. 1997. International diversification: Effects on innovation and firm performance in product-diversified firms. Academy of Management Journal, 40 (4): 767-798.

Hsuan, J., \& Mahnke, V. 2011. Outsourcing R\&D: A review, model, and research agenda. $R \& d$ Management, 41(1): 1-7.

Ivarsson, I. 2002. Transnational corporations and the geographical transfer of localised technology: A multi-industry study of foreign affiliates in Sweden. Journal of Economic Geography, 2 (2): 221-247.

Ivus, O., Park, W. G., \& Saggi, K. 2017. Patent protection and the composition of multinational activity: Evidence from US multinational firms. Journal of International Business Studies, 48 (7): 808-836.

Jaffe, A. B., Trajtenberg, M., \& Henderson, R. 1993. Geographic localization of knowledge spillovers as evidenced by patent citations. The Quarterly Journal of Economics, 108(3): 577-598.

Kafouros, M., \& Aliyev, M. 2016. Institutional development and firm profitability in transition economies. Journal of World Business, 51(3): 369-378.

Kafouros, M., Buckley, P. J., \& Clegg, J. 2012. The effects of global knowledge reservoirs on the productivity of multinational enterprises: The role of international depth and breadth. Research Policy, 41(5): 848-861.

Kafouros, M., Wang, C., Mavroudi, E., Hong, I., \& Katsikeas, C. S. 2018. Geographic dispersion and co-location in global R\&D portfolios: Consequences for firm performance. Research Policy, 47(7): 1243-1255.

Kaplan, S., \& Vakili, K. 2015. The double-edged sword of recombination in breakthrough innovation. Strategic Management Journal, 36(10): 1435-1457. 
Khanna, T., Gulati, R., \& Nohria, N. 1998. The dynamics of learning alliances: Competition, cooperation, and relative scope. Strategic Management Journal, 19(3): 193-210.

Kogut, B., \& Zander, U. 1992. Knowledge of the firm, combinative capabilities, and the replication of technology. Organization Science, 3(3): 383-397.

Kogut, B., \& Zander, U. 1993. Knowledge of the firm and the evolutionary theory of the multinational corporation. Journal of International Business Studies, 24(4): 625-645.

Kogut, B., \& Zander, U. 1995. Knowledge, market failure and the multinational enterprise: A reply. Journal of International Business Studies, 26(2): 417-426.

Lahiri, N. 2010. Geographic distribution of R\&D activity: HOW does it affect innovation quality? Academy of Management Journal, 53(5): 1194-1209.

Laursen, K., \& Salter, A. 2006. Open for innovation: The role of openness in explaining innovation performance among UK manufacturing firms. Strategic Management Journal, 27(2): 131-150.

Lee, S. H., \& Song, S. 2012. Host country uncertainty, intraMNC production shifts, and subsidiary performance. Strategic Management Journal, 33(11): 1331-1340.

Leiponen, A., \& Helfat, C. E. 2010. Innovation objectives, knowledge sources, and the benefits of breadth. Strategic Management Journal, 31(2): 224-236.

Lerner, J. 1994. The importance of patent scope: An empirical analysis. The RAND Journal of Economics, 25(2): 319-333.

Levinthal, D. A., \& March, J. G. 1993. The myopia of learning. Strategic Management Journal, 14(2): 95-112.

Lew, Y. K., Sinkovics, R. R., Yamin, M., \& Khan, Z. 2016. Transspecialization understanding in international technology alliances: The influence of cultural distance. Journal of International Business Studies, 47(5): 577-594.

Liu, X., Lu, J., Filatotchev, I., Buck, T., \& Wright, M. 2010. Returnee entrepreneurs, knowledge spillovers and innovation in high-tech firms in emerging economies. Journal of International Business Studies, 41(7): 1183-1197.

Lockett, A., Wiklund, J., Davidsson, P., \& Girma, S. 2011. Organic and acquisitive growth: Re-examining, testing and extending Penrose's growth theory. Journal of Management Studies, 48(1): 48-74.

Lu, J. W., \& Beamish, P. W. 2001. The internationalization and performance of SMEs. Strategic Management Journal, 22(6-7): 565-586.

Madhok, A. 1997. Cost, value and foreign market entry mode: The transaction and the firm. Strategic Management Journal, 18(1): 39-61.

Mahoney, J. T., \& Pandian, J. R. 1992. The resource-based view within the conversation of strategic management. Strategic Management Journal, 13(5): 363-380.

March, J. G. 1991. Exploration and exploitation in organizational learning. Organization Science, 2(1): 71-87.

Martin, X., \& Salomon, R. 2003. Knowledge transfer capacity and its implications for the theory of the multinational corporation. Journal of International Business Studies, 34(4): 356-373.

Martinez-Noya, A., \& Narula, R. 2018. What more can we learn from R\&D alliances? A review and research agenda. BRQ Business Research Quarterly, 21(3): 195-212.

Meyer, K. E., Van Witteloostuijn, A., \& Beugelsdijk, S. 2017. What's in a $p$ ? Reassessing best practices for conducting and reporting hypothesis-testing research. Journal of International Business Studies, 48(5): 535-551.

Miller, D. J., Fern, M. J., \& Cardinal, L. B. 2007. The use of knowledge for technological innovation within diversified firms. Academy of Management Journal, 50(2): 307-325.

Monteiro, F., \& Birkinshaw, J. 2017. The external knowledge sourcing process in multinational corporations. Strategic Management Journal, 38(2): 342-362.
Monteiro, F., Mol, M., \& Birkinshaw, J. 2017. Ready to be open? Explaining the firm level barriers to benefiting from openness to external knowledge. Long Range Planning, 50(2): 282-295.

Mowery, D. C., Oxley, J. E., \& Silverman, B. S. 1996. Strategic alliances and interfirm knowledge transfer. Strategic Management Journal, 17(2): 77-91.

Mudambi, R. \& Swift, T. 2011. Leveraging knowledge and competencies across space: The next frontier in international business. Journal of International Management, 17(3): 186189.

Narula, R. 2001. Choosing between internal and non-internal R\&D activities: Some technological and economic factors. Technology Analysis \& StrategicManagement, 13(3): 365-387.

Narula, R. 2014. Globalization and technology: Interdependence, innovation systems and industrial policy. New York: Wiley.

Narula, R., \& Hagedoorn, J. 1999. Innovating through strategic alliances: Moving towardsinternational partnerships and contractual agreements. Technovation, 19(5): 283-294.

Narula, R., \& Santangelo, G. D. 2009. Location, collocation and R\&D alliances in the European ICT industry. Research Policy, 38 (2): 393-403.

Narula, R., \& Verbeke, A. 2015. Making internalization theory good for practice: The essence of Alan Rugman's contributions to international business. Journal of World Business, 50(4): 612622.

Nieto, M. J., \& Santamaría, L. 2007. The importance of diverse collaborative networks for the novelty of product innovation. Technovation, 27(6-7): 367-377.

Noorderhaven, N., \& Harzing, A.-W. 2009. Knowledge-sharing and social interaction within MNEs. Journal of International Business Studies, 40(5): 719-741.

Park, W. G. 2008. International patent protection: 1960-2005. Research Policy, 37(4): 761-766.

Patel, P. C., Fernhaber, S. A., McDougall-Covin, P. P., \& van der Have, R. P. 2014. Beating competitors to international markets: The value of geographically balanced networks for innovation. Strategic Management Journal, 35(5): 691-711.

Paternoster, R., Brame, R., Mazerolle, P., \& Piquero, A. 1998. Using the correct statistical test for the equality of regression coefficients. Criminology, 36(4): 859-866.

Penrose, E. T. 1959. The theory of the growth of the firm. Oxford: Oxford University Press.

Phene, A., \& Almeida, P. 2008. Innovation in multinational subsidiaries: The role of knowledge assimilation and subsidiary capabilities. Journal of International Business Studies, 39(5): 901-919.

Phene, A., Fladmoe-Lindquist, K., \& Marsh, L. 2006. Breakthrough innovations in the US biotechnology industry: The effects of technological space and geographic origin. Strategic Management Journal, 27(4): 369-388.

Phene, A., \& Tallman, S. 2018. Subsidiary development of new technologies: Managing technological changes in multinational and geographic space. Journal of Economic Geography, 18(5): 1121-1148.

Porter, M. E., Sala-i-Martin, X., Lopez-Carlos, A., \& Schwab, K. 2004. World economic forum survey: The global competitiveness report 2003-2004. Oxford: Oxford University Press.

Qian, G., Khoury, T. A., Peng, M. W., \& Qian, Z. 2010. The performance implications of intra-and inter-regional geographic diversification. Strategic Management Journal, 31(9): 1018-1030.

Richard, P. J., Devinney, T. M., Yip, G. S., \& Johnson, G. 2009. Measuring organizational performance: Towards methodological best practice. Journal of Management, 35(3): 718804.

Rigby, D., \& Zook, C. 2002. Open-market innovation. Harvard Business Review, 80(10): 80-93.

Roberts, P. W. 1999. Product innovation, product-market competition and persistent profitability in the US pharmaceutical industry. Strategic Management Journal, 20(7): 655-670. 
Robertson, T. S., \& Gatignon, H. 1998. Technology development mode: A transaction cost conceptualization. Strategic Management Journal, 19(6): 515-531.

Roodman, D. 2009. How to do xtabond2: An introduction to difference and system GMM in Stata. Stata Journal, 9(1): 86136.

Rosenkopf, L., \& Nerkar, A. 2001. Beyond local search: boundary-spanning, exploration, and impact in the optical disk industry. Strategic Management lournal, 22(4): 287-306.

Rugman, A. M. 1981. Inside the multinationals. London: Croom Helm.

Salomon, R., \& Jin, B. 2008. Does knowledge spill to leaders or laggards? Exploring industry heterogeneity in learning by exporting. Journal of International Business Studies, 39(1): 132150.

Sanna-Randaccio, F., \& Veugelers, R. 2007. Multinational knowledge spillovers with decentralised R\&D: A game-theoretic approach. Journal of International Business Studies, 38(1): 47-63.

Santangelo, G. D., Meyer, K. E., \& Jindra, B. 2016. MNE subsidiaries' outsourcing and insourcing of R\&D: The role of local institutions. Global Strategy Journal, 6(4): 247-268.

Scalera, V. G., Perri, A., \& Hannigan, T. J. 2018. Knowledge connectedness within andacross home country borders: Spatial heterogeneity and the technological scope offirm innovations. Journal of International Business Studies, 49(8): 9901009.

Singh, J., \& Fleming, L. 2010. Lone inventors as sources of breakthroughs: Myth or reality? Management Science, 56(1): 41-56.

Sørensen, J. B., \& Stuart, T. E. 2000. Aging, obsolescence, and organizational innovation. Administrative Science Quarterly, 45 (1): 81-112.

Squicciarini, M., Dernis, H. \& Criscuolo, C. 2013. Measuring patent quality: Indicators of technological and economic value. OECD Science, Technology and IndustryWorking Papers, 2013/03, OECD Publishing.

Srivastava, M. K., \& Gnyawali, D. R. 2011. When do relational resources matter? Leveraging portfolio technological resources for breakthrough innovation. Academy of Management Journal, 54(4): 797-810.

Stuermer, M., Spaeth, S., \& Von Krogh, G. 2009. Extending private-collective innovation: A case study. $R \& d$ Management, 39(2): 170-191.

Tallman, S., \& Li, J. 1996. Effects of international diversity and product diversity on the performance of multinational firms. Academy of Management Journal, 39(1): 179-196.

Teece, D. J. 1982. Towards an economic theory of the multiproduct firm. Journal of Economic Behavior \& Organization, 3(1): 39-63.

Teece, D. J. 1986. Profiting from technological innovation: Implications for integration, collaboration, licensing and public policy. Research Policy, 15(6): 285-305.

Trajtenberg, M. 1990. A penny for your quotes: Patent citations and the value of innovations. The Rand journal of Economics, 21 (1): 172-187.

Verardi, V., \& Croux, C. 2009. Robust regression in Stata. The Stata Journal, 9(3): 439-453.

Veugelers, R. 1997. Internal R\&D expenditures and external technology sourcing. Research Policy, 26(3): 303-315.

Von Zedtwitz, M., \& Gassmann, O. 2002. Market versus technology drive in R\&D internationalization: Four different patterns of managing research and development. Research Policy, 31(4): 569-588.

Wagner, S., Hoisl, K., \& Thoma, G. 2014. Overcoming localization of knowledge-The role of professional service firms. Strategic Management Journal, 35(11): 1671-1688.

West, J., Salter, A., Vanhaverbeke, W., \& Chesbrough, H. 2014. Open innovation: The next decade. Research Policy, 43(5): 805-811.
White, S., \& Siu-Yun Lui, S. 2005. Distinguishing costs of cooperation and control in alliances. Strategic Management Journal, 26(10): 913-932.

Wooldridge, J. M. 2009. On estimating firm-level production functions using proxy variables to control for unobservables. Economics Letters, 104(3): 112-114.

Yamin, M., \& Otto, J. 2004. Patterns of knowledge flows and MNE innovative performance. Journal of International Management, 10(2): 239-258.

Zaheer, S. 1995. Overcoming the liability of foreignness. Academy of Management Journal, 38(2): 341-363.

Zahra, S. A., \& George, G. 2002. Absorptive capacity: A review, reconceptualization, and extension. Academy of Management Review, 27(2): 185-203.

Zanfei, A. 2000. Transnational firms and the changing organisation of innovative activities. Cambridge Journal of Economics, 24(5): 515-542.

\section{ABOUT THE AUTHORS}

Mario Kafouros holds the Chair of International Business and Innovation at Alliance Manchester Business School (University of Manchester, UK), where he is also the Head of Division (PMO). He has extensive industrial and academic experience in the field of innovation and international business and strategy, he is Senior Editor of International Business Review, and his research has been published in leading journals, including the Journal of Management, Journal of International Business Studies, Journal of Management Studies and Research Policy.

Niron Hashai is a Full Professor at the Arison School of Business (Reichman University) and Visiting Professor at Alliance Manchester Business School (UK). His research interests include: theory of the multinational corporation, technological innovation, diversification, and growth patterns of high technology firms. His research has been published in top strategy, management, international business and innovation journals, including: Journal of International Business Studies, Journal of Management, Research Policy, Strategic Management Journal and Strategy Science.

Janja Annabel Tardios is a Lecturer in Strategy and International Business at Brunel Business School, Brunel University London. She holds a doctorate in Business and Economics from the University of Leeds and a MSc in International Business from the University of Essex, UK. Her research interests include the internationalization strategies of multinational enterprises and their impact.

Elizabeth Yi Wang is an Associate Professor of International business. Her research focuses on multilevel operations of firms, capability building 
of emerging market firms, green innovation, and carrying capacity. She is a Senior Fellow of the Higher Education Academy, a recipient of the Women of Achievement Award, and founder of the
Mainstreaming Impact in International Business Initiative.

Publisher's Note Springer Nature remains neutral with regard to jurisdictional claims in published maps and institutional affiliations.

Accepted by Rajneesh Narula, 26 November 2021. This article has been with the authors for three revisions. 